Alessandra Corallo Nicacio

\title{
AVALIAÇÃO DO DESENVOLVIMENTO APÓS A CRIOPRESERVAÇÃO DE EMBRIÕES BOVINOS PRODUZIDOS IN VITRO
}

São Paulo

2008 


\section{Alessandra Corallo Nicacio}

\section{AVALIAÇÃO DO DESENVOLVIMENTO APÓS A CRIOPRESERVAÇÃO DE EMBRIÕES BOVINOS PRODUZIDOS IN VITRO}

Tese apresentada ao Programa de Pósgraduação em Reprodução Animal da Faculdade de Medicina Veterinária e Zootecnia da Universidade de São Paulo para obtenção de título de Doutor em Medicina Veterinária

Departamento:

Reprodução Animal

Área de concentração:

Reprodução Animal

Orientador:

Prof. Dr. José Antônio Visintin

São Paulo

2008 
Autorizo a reprodução parcial ou total desta obra, para fins acadêmicos, desde que citada a fonte.

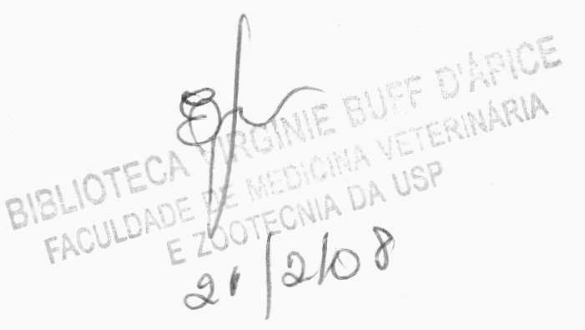

DADOS INTERNACIONAIS DE CATALOGAÇÃO-NA-PUBLICAÇÃO

(Biblioteca Virginie Buff D’Ápice da Faculdade de Medicina Veterinária e Zootecnia da Universidade de São Paulo)

T.1954 Nicacio, Alessandra Corallo

FMVZ Avaliação do desenvolvimento após a criopreservação de embriōes bovinos produzidos in vitro / Alessandra Corallo Nicacio.

- São Paulo: A. C. Nicacio, 2008.

$109 \mathrm{f}$ : : il.

Tese (doutorado) - Universidade de São Paulo. Faculdade de Medicina Veterinária e Zootecnia. Departamento de Reprodução Animal.

Programa de Pós-Graduação: Reprodução Animal.

Área de concentração: Reprodução Animal.

Orientador: Prof. Dr. José Antônio Visintin.

1. Criopreservação. 2. Embriões bovinos. 3. Fecundação in vitro. 4. Expressão gênica. 5. Cultivo embrionário. I. Título. 


\section{UNIVERSIDADE DE SÃO PAULO \\ Faculdade de Medicina Veterinária e Zootecnia}

Cidade Universitária "Armando de Salles Oliveira"

Comissão Bioética

\section{CERTIFICADO}

Certificamos que o Projeto intitulado "Avaliação do desenvolvimento após a criopreservação de embriões bovinos produzidos in vitro", protocolo n 566/2004, utilizando oócitos de matadouro, sob a responsabilidade do Prof. Dr. José Antonio Visintin, está de acordo com os princípios éticos de experimentação animal da Comissão de Bioética da Faculdade de Medicina Veterinária e Zootecnia da Universidade de São Paulo e foi aprovado "ad referendun".

(We certify that the Research "Evaluation of development after criopreservation of in vitro produced bovine embryos", protocol number 566/2004, under the responsibility of Prof. Dr. José Antonio Visintin agree with Ethical Principles in Animal Research adopted by Bioethic Commissior of the Faculty of Veterinary Medicine and Zootechny of University of São Paulo and was approved "ad referendun", meeting).

São Paulo, 21 de dezembro de 2004

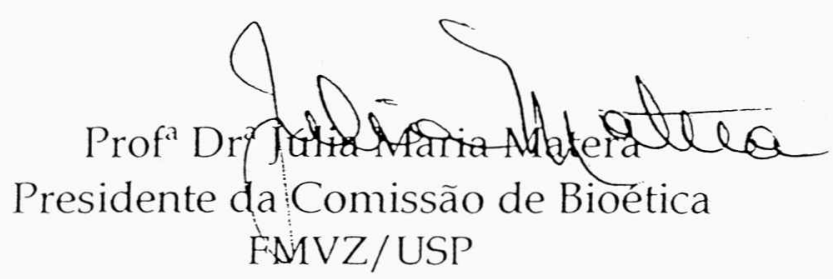

Av. Prof. Dr. Orlando Marques de Paiva, 87 - 05508-000 - Cid. Univ. "Armando de Salles Oliveira" Fones: (011) 3091-7671/3091-7676 Fax: (011) 3032-2224 
FOLHA DE AVALIAÇÃO

Nome: NICACIO, Alessandra Corallo

Título: Avaliação do desenvolvimento após a criopreservação de embriões bovinos produzidos in vitro

Tese apresentada ao Programa de Pós-graduação em Reprodução Animal da Faculdade de Medicina Veterinária e Zootecnia da Universidade de São Paulo para obtenção do título de Doutor em Medicina Veterinária

Data: _ I_ I

Banca Examinadora

Prof. Dr. Instituição:

Assinatura: Julgamento:

Prof. Dr. Instituição:

Assinatura: Julgamento:

Prof. Dr. Instituição:

Assinatura: Julgamento:

Prof. Dr. Instituição:

Assinatura: Julgamento:

Prof. Dr. Instituição:

Assinatura: Julgamento: 


\begin{abstract}
À minha mãe (Nilsa - Mamis) e ao meu pai
(Norson-Papito), por serem mais que pais, por serem meus eternos exemplos de vida, meus portos seguros, meus alicerces, meu tudo. Sem vocês eu nunca seria quem sou!!! Obrigada.
\end{abstract}

Amo vocês!!!! 


\section{Agradecimentos}

Carnaval de 2002: eu, vários textos pra estudar, várias dúvidas, muitas perguntas. A biologia molecular olhando pra mim e eu pra ela, mas qual técnica escolher? E o maior problema de todos: escrever meu projeto de doutorado.

Carnaval de 2008: eu, vários textos lidos e estudados, alguns ainda por ler, várias dúvidas e perguntas. E a maior questão: como explico isso?

Bom, não tem como negar, nestes últimos quatro anos muita coisa aconteceu. Passei horas no laboratório (tá, isso não é novidade!), mas também descobri um mundo maravilhoso fora dele (agora sim, uma novidade!). Descobri que nem tudo sai como a gente espera e planeja, aprendi a me virar quando tudo está dando errado. Aprendi a errar e a concertar o que fiz de errado. Mas acima de tudo, aprendi a manter a cabeça erguida, sempre em frente, porque desistir dos meus objetivos eu nunca vou aprender! Aprendi que tenho amigos maravilhosos que sempre estão disponíveis para um conselho, uma piada, uma brincadeira, uma balada, um apoio, uma lágrima, um desabafo, ou só para ficar quieto ao meu lado. Aprendi que tem gente ruim no mundo, mas para cada pessoa ruim existem uns dez amigos para compensar. Aprendi que família a gente não escolhe, tem que agüentar do jeito que é, afinal, ela também te agüenta do jeito que você teima ser... Aprendi que ser gente grande não é fácil. Que o tempo não volta atrás. Mas também aprendi que o tempo que passou me fez ser assim, desse jeitinho mesmo. E desta história de aprendizado, sobraram muitas lembranças e muitos agradecimentos a serem feitos.

Primeiro preciso agradecer ao meu orientador. Visintin (meu eterno chefinho), há alguns anos atrás, ouvi dizer que "um tal de Prof. Visintin dá estágio no VRA". Fui quem era esse professor. Procurei nas placas das portas qual era sala dele e pedi licença. Naquele dia, eu não fazia idéia do que eu estava fazendo, não sabia quanto aquele momento seria crucial pra minha vida depois. Você mudou minha visão de mundo, de trabalho, de profissão, de dedicação. Obrigada por me aceitar no seu grupo de trabalho, por entender até o que eu não expliquei e, principalmente, por no pior momento, ser meu orientador. Sinto que sou abençoada por essa convivência $e$ por esses anos todos.

Depois tenho que agradecer os verdadeiros responsáveis por eu chegar aqui: meus pais. Papito e Mamis, sem o apoio e o exemplo de vocês eu nunca teria caminhado 
nem um metro, quanto mais chegar até aqui. Sei que a vida anda complicada para todos nós, mas também que meu porto seguro sempre será vocês. E quero sempre poder retribuir isso e tudo mais que vocês sempre foram, são e serão para mim.

Mas não posso esquecer alguém tão importante quanto meus pais: minha tia Ruth. Tia, um coração gigante como o seu é um presente para o mundo. Obrigada por ser assim, tão minha tia querida, por agüentar cada momento bom e ruim sempre ao meu lado. Sei que posso contar com você e queria que você soubesse que seu lugar no meu coração é mais que especial, é só seu.

Bruno, apesar de você só ter participado de uma pequena parte de tudo isso, você chegou num momento mega difícil e me ajudou a ver que nem tudo estava perdido. Graças a você eu consegui rir, mesmo estando no meio da lama; consegui chorar quando não tinha mais lágrima; consegui terminar quando não tinha mais esperança. Obrigada pela paciência, pelo apoio e pelo carinho.

E tem também o meu irmão. Junior, apesar do pouco tempo que passamos juntos, com nossas vidas corridas e opostas, não posso negar, são momentos muito divertidos.

Isso sem esquecer dos meus 3 anjos da guarda caseiros: Maria Helena, Marinalva e Regina. Sem a gigantesca ajuda de vocês esse trabalho não seria feito e eu estaria doidinha de pedra.

Agora as coisas vão ficando mais complicadas, não posso esquecer ninguém. Vou começar pelo laboratório.

Mayra, minha co-orientadora, mais do que isso, minha amiga. Porque cada vez que te procurei pra conversar, fosse sobre trabalho, sobre mocinhos, sobre minha família, ou sei lá, qualquer assunto aleatório, sempre tinha um abraço gostoso me esperando. Obrigada! E porque, quando no fim do dia, tudo parecia negro e cansado tinha seus meninos no corredor. O Xi e o João são a alegria do corredor no fim de tarde. Só não sei se hoje vamos jogar bola, brincar de pega-pega ou de esconder.

Aos amigos e colegas de laboratório: Alê Brandão (sumida, está sempre em Pira, mas quando aparece sua risada anima todo mundo), Bianca (pouco tempo de convivência, mas já sei que você é um amor), Camilla (que de estagiária passou a salva-vidas, obrigada), Fabíola (também pode tentar a carreira de salva-vida, tem futuro, 
obrigada também), Febém (que a corda no pescoço não sufoque nunca mais a gente), Fernanda (também pouca convivência, mas com umas conversas bem divertidas), Flávia (você pediu, eu fiquei mais tempo, lembra?), Marãn (entre a anatomia e o VRA, quando não tem canil pra limpar tem ovário pra aspirar), Mari Groke (de uma colega a amiga e companheira em todos esses anos juntas), Mariana (agora que você parou de entrar pela janela ficou mais fácil conversar), Paulo (o "caçula" do laboratório, fica esperto senão não sai nunca daqui), Rê (minha muleta e companheira), Maza (também está seguindo por novos caminhos, que a docência te ensine tanto quanto eu venho aprendendo), Weber (mesmo longe lembrei de você), Zeca (já sei de onde vem toda sua superação, obrigada).

Aos antigos amigos de laboratório que também muito me ensinaram: Cássia (outra boa alma que tive e tenho a felicidade de ser amiga), Creysson (uma alma boa que tive a felicidade de conviver, você vai brilhar cada dia mais, seja onde for), Helô (posso falar pouco com você hoje em dia, mas você sabe que sempre acreditei em você), Marcão (amigo e exemplo), Nani (passou na minha frente, mas eu também consegui terminar), Vivi (sem palavras, basta pensar em você que o telefone toca). E agora vou passar pelo departamento.

Aos amigos de departamento, de ontem e de hoje: Cabral, Camila Vannuchi, Claudinha, Cristina, Everton, Gabriel, Gisele, Henderson, Jaqueline, Liege, Lindsay, Ludy, Marcílio, Manuel, Mariana, Marie, Nélcio, Paola, Patrícia, Paulo, Priscila, Torres, Zé Nélio e muitos mais. A convivência com todos vocês fez meus dias mais felizes, minha rotina mais amena e os churrascos mais divertidos. Vou sentir falta de vocês.

Aos amigos e funcionários: Alice, Belau, Harumi, Iraílton, Jocimar, Luis, Maria Amélia, Miguel, Dona Silvia, Taís. Cada "bom dia" que recebi, cada copo de café, cada brincadeira de corredor, ou mesmo conversa serviram como uma maneira de continuar tocando a rotina pesada de uma maneira mais amena.

À amiga Lígia (FZEA - USP), que apareceu com a maior boa vontade e ajudou muito, num momento muito negro do trabalho. Nunca vou esquecer a ajuda $e 0$ apoio. Obrigada!!!

E agora aos amigos, de diferentes lugares, mas sempre amigos! 
Cris, Liege e Lindsay, em especial, não só pelos almoços divertidos, nem só pelas baladas, nem só pelo grupo de estudo, ou pelas risadas, mas pelas conversas sérias, pelas discussões filosóficas das nossas vidas, enfim, pela amizade sincera. Que este quarteto continue sempre assim, unido, mesmo que sem todos os almoços...

Rê, pelas mil MIV(s), FIV(s), CIV(s), Feeding(s), meios e tudo mais (que você me proibiu de pagar em chocolate), pela amizade de hoje e sempre, pela companhia das marmitas, pelas conversas no "fumódromo", pelas idas ao Dedo (e outras baladinhas), por tudo. Valeu!!!

Mari, depois de tantos anos fico feliz em dizer: aprendi a ser sua amiga. Porque amigo está sempre junto, na alegria e na tristeza, na república ou em casa, no trabalho ou no "happy hour", o importante é saber ouvir e ajudar, é saber apoiar e entender. $E$ isso, nós aprendemos, né?!

Vivi, não sei nem como agradecer tanta amizade, tantas conversas, tantas broncas necessárias, tantas risadas e mais risadas. Você é uma pessoa que ilumina tudo ao seu redor. Queria que você tivesse a certeza que sua luz continua chegando aqui em São Paulo, via email, via telefone, via telepatia...

Marcão, já disse uma vez e repito, se aprendi e fiz tudo o que está aqui foi graças a você e sua ajuda. A gente até some de vez em quando, mas de repente alguém pára $e$ escreve para lembrar o outro que a amizade está acima de todo o monte de trabalho.

À amiga Silvia, um presente que recebi na hora em que eu mais precisava, um empurrão que me fez andar vários anos pra frente. Obrigada!

À ex-aluna que hoje é uma grande amiga Letícia, se alguém um dia acreditou em mim foi você. E se alguém acredita em você sou eu, segue seu caminho, porque seu futuro será brilhante, tenho certeza!

Aos amigos de faculdade: Bioka, But's, Carol, Cururu, Garibas, Guiga, Gump, Kitty, Kussô, Minnie, Mikuin, Nicole, Waleska, Xeila. Seja da turma que for, falando sempre ou só de vez em quando, o importante é a amizade e o companheirismo.

Aos amigos da turma: Val, Grego, Giovanni, Nato, Taci, Pri, Alê, Caio, Vivi, Arthur, Grillo, Cipola, Ozinho, Paulo, Ciça, Gé, Douglas, Simone, Alex, Michele, Alex, 
Matheus, Lucas, Rodolpho, Pat, Gigio, Luciana, Érika, Lourenço, Flávia, Marcão, Mirela e todos os lambers. Porque amigos como vocês fazem a gente ver que nada é tão ruim que seja eterno, que sempre tem uma luz no fim do túnel, e que no final do ano estamos todos reunidos.

Amiga Alê, mesmo sem a gente conversar muito nos últimos tempos nossa amizade está acima de tudo, basta sobrar uns minutos que as fofocas ficam em dia.

Amiga Sandra, sempre companheira, para um cinema, para um chopp, para comer um chocolate, ler e discutir sobre um bom livro, tanto faz, desde que a gente esteja conversando está ótimo!

Meus primeiros alunos, em especial, Aline, Amanda, André, Bruno, Flávio, Guilherme, Gonzo, Letícia, Luna, Márcia, Mariana, Natália, Roberta, Shellen, vocês me fizeram ver que a amizade não tem preconceito.

Ao Departamento ao Programa de Pós-graduação Reprodução Animal por me acolher por todos esses anos. Assim como à Faculdade de Medicina e Veterinária e Zootecnia da Universidade de São Paulo, meu lar e meu orgulho. Passei mais horas da minha vida aqui do que consigo contar. Sou muito feliz por isso!

À FAPESP pelo apoio financeiro, fornecendo a bolsa que permitiu a execução deste trabalho.

E por fim, agradeço a Murphy e suas bem humoradas leis, afinal "Se alguma coisa tem a mais remota chance de dar errado, certamente dará". 
"E agora, José?

A festa acabou,

a luz apagou,

o povo sumiu,

a noite esfriou,

e agora, José?

e agora, você? (...)"

(Carlos Drummond de Andrade)

\author{
"A dor é inevitável \\ O sofrimento é opcional" \\ (Carlos Drummond de Andrade)
}




\section{RESUMO}

NICACIO, A. C. Avaliação do desenvolvimento após a criopreservação de embriões bovinos produzidos in vitro. [Evaluation of development after cryopreservation of in vitro bovine produced embryos]. 2008 109f. Tese (Doutorado em Medicina Veterinária) - Faculdade de Medicina Veterinária e Zootecnia, Universidade de São Paulo, São Paulo, 2008.

A ineficiência dos protocolos de criopreservação limita o uso em larga escala da produção in vitro de embriões bovinos. O objetivo deste trabalho foi identificar os danos causados pela criopreservação e pelo cultivo embrionário de embriões bovinos produzidos in vitro após a descongelação, avaliando a morfologia, a expressão gênica e o desenvolvimento in vitro antes e após a criopreservação. Complexos cummulusoócitos foram maturados, fecundados e cultivados in vitro. Blastocistos expandidos ( $n=600$ ) obtidos entre os dias 7 e 9 de cultivo (fecundação D0) foram submetidos a congelação controlada (grupo controlado: 10\% de etileno glicol (EG) por 10 minutos, $1,2^{\circ} \mathrm{C}$ por minuto), congelação rápida (grupo rápido: $10 \%$ de EG por 10 minutos , 20\% de $E G+20 \%$ de Glicerol (Gli) por 30 segundos) ou vitrificação (grupo vitrificação: 10\% de EG por 10 minutos, 25\% EG + 25\% Gli por 30 segundos). Os embriões do grupo controle não foram expostos a crioprotetores e nem a protocolos de criopreservação, sendo avaliado o índice de eclosão 12 dias após a fecundação (46,09\%). As palhetas para os protocolos de congelação rápida e vitrificação foram mantidas em vapor de nitrogênio líquido $(0,8 \mathrm{~cm}$ sobre o líquido) por 2 minutos e imersas no nitrogênio líquido. Os embriões foram descongelados por 10 segundos em ar e 20 segundos em banhomaria a $25^{\circ} \mathrm{C}$. Os embriões foram reidratados em solução de PBS + 0,2\% de BSA + $0,3 \mathrm{M}$ de sacarose e em solução de PBS + 0,2\% de BSA ambos por 3 minutos. Para avaliar o desenvolvimento, os embriões, após a descongelação, foram co-cultivados com células da granulosa em meio TCM199 ou SOFaa por 4 dias. Os dados foram analisados com o aplicativo PROC MIXED do programa SAS Sistems for Windows ${ }^{\circ}$. O

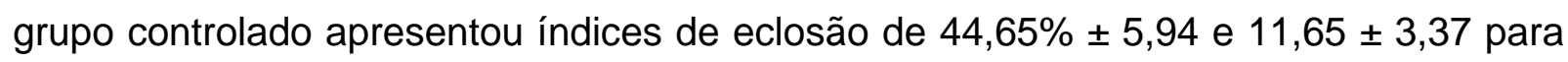
o meio TCM199 e para o meio SOFaa, respectivamente. Embriões do grupo rápido não apresentaram eclosão, independente do meio de cultivo. O grupo vitrificação apresentou índices de eclosão de 9,43\% \pm 6,77 e 8,67\% \pm 4,47, respectivamente, em 
meio TCM199 e SOFaa. Os valores foram significativos quando $p<0,05$. O grupo controlado apresentou diferença em relação aos outros grupos em ambos os meios de cultivo. No meio TCM199 os índices de re-expansão e eclosão foram mais altos. Para a análise da expressão gênica, 2 pools de 10 blastocistos expandidos de embriões frescos e criopreservados (congelação controlada) foram utilizados para a extração de RNA. Foi feita reação de Transcrição Reversa (RT-PCR) e de PCR em Tempo Real. Os resultados da reação de PCR em Tempo Real demonstraram que a quantidade de material não foi suficiente para a amplificação de produtos em todas as reações. Concluindo, o meio de cultivo TCM199 exerce influência sobre o desenvolvimento embrionário após a criopreservação, sendo mais apropriado do que o meio SOFaa. E, para proceder a análise da expressão gênica pela reação de PCR em Tempo Real é necessário número maior de blastocistos expandidos.

Palavras-chave: Criopreservação. Embriões bovinos. Fecundação in vitro. Expressão gênica. Cultivo embrionário. 


\begin{abstract}
NICACIO, A. C. Evaluation of development after cryopreservation of in vitro bovine produced embryos. [Avaliação do desenvolvimento após a criopreservação de embriões bovinos produzidos in vitro]. 2008 109f. Tese (Doutorado em Medicina Veterinária) - Faculdade de Medicina Veterinária e Zootecnia, Universidade de São Paulo, São Paulo, 2008.

The inefficiency of embryo cryopreservation protocols limits the broad use of in vitro production (IVP) of bovine embryos. The aim of this work was to identify the damage caused by cryopreservation and embryo culture of in vitro produced bovine embryos after thawing by morphological analysis, gene expression and in vitro development before and after cryopreservation. Cummulus-oocyte complexes were in vitro matured, fertilized and cultured. Expanded blastocysts $(n=600)$ harvested on days 7-9 were submitted controlled freezing [controlled group: 10\% ethylene glycol (EG) for 10 minutes and $1.2^{\circ} \mathrm{C}$ per minute cryopreservation], quick-freezing [quick group: $10 \%$ EG for 10 minutes, $20 \%$ EG $+20 \%$ Glycerol (Gly) for 30 seconds] or vitrification [vitrification group: $10 \%$ EG for 10 minutes, $25 \%$ EG $+25 \%$ Gly for 30 seconds] protocols. The embryos of the control group were not exposed to cryoprotectant or crypreservation method and the hatching rate was evaluated on day12 post-insemination. The straws (quick and vitrification groups) were first placed on nitrogen vapor (0.8 cm over the liquid nitrogen) for 2 minutes and than immersed in liquid nitrogen. Embryos were thawed in air for 10 seconds followed by $25^{\circ} \mathrm{C}$ water bath for 20 seconds. Embryos were rehydrated in PBS $+0.2 \%$ BSA + 0.3M sucrose for 3 minutes and PBS + 0.2\% BSA for the same time. In order to evaluate development of frozen-thawed embryos they were cocultured on granulosa cells in TCM 199 or SOFaa for 4 days. Hatching rate of control group was 46.09\%. Data was analyzed by PROC MIXED model of SAS Sistems for Windows ${ }^{\circledR}$. Controlled group hatching rate was $44.65 \% \pm 5.94$ and $11.65 \% \pm 3.37$ for TCM 199 and in SOFaa, respectively. Embryos submitted to quick group did not hatch regardless of culture condition. Vitrification group showed hatching rates of $9.43 \% \pm 6.77$ and $8.67 \%$ \pm 4.47 , respectively, in TCM 199 and SOFaa., and values were significant at $p<0.05$. The controlled group showed difference between the other groups of cryopreservation in both medium (TCM 199 and SOFaa). However, TCM 199 showed high rates of re-
\end{abstract}


expansion and hatching. To gene expression analysis, 2 pools of 10 expanded blastocysts of fresh and cryopreserved embryos (controlled freezing) was used to RNA extraction, Reverse Transcription PCR (RT-PCR) was done and submitted to a Real Time PCR. The results of the Real Time PCR showed that the amount of material was not enough to the amplification of products in all reactions. In conclusion, the culture medium influences the embryo development after the cryopreservation being TCM199 more appropriate than SOFaa. And more number of expanded blastocysts is necessary to analysis the gene expression in a Real Time PCR reaction.

Key words: Cryopreservation. Bovine embryos. In vitro production. Gene expression. Embryo culture. 


\section{SUMÁRIO}

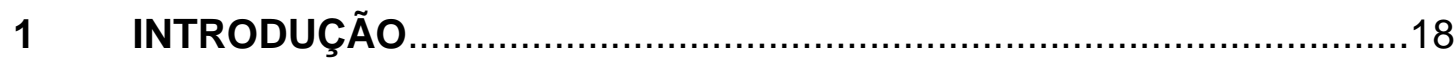

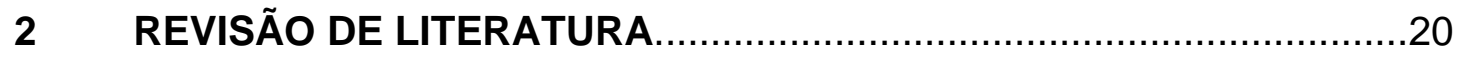

2.1 Panorama da produção in vitro de embriões...................................21

2.2 Desenvolvimento embrionário........................................................22

2.3 Efeitos do cultivo in vitro sobre a qualidade embrionária........................24

2.4 Diferenças entre embriões produzidos in vitro e in vivo.........................27

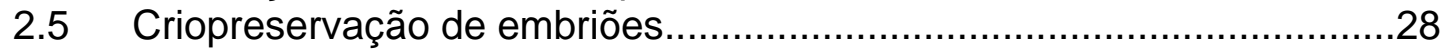

2.6 Fatores que influenciam a criopreservação de embriões......................29

2.7 Danos que a criopreservação pode causar aos embriões......................30

2.8 Estratégias para evitar os danos embrionários durante a

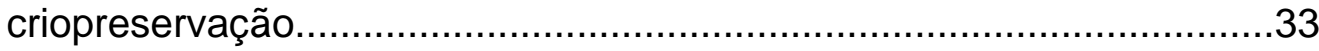

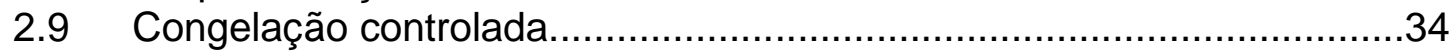

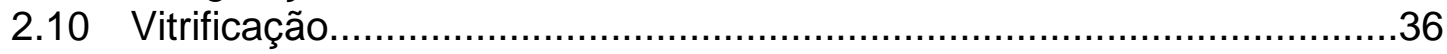

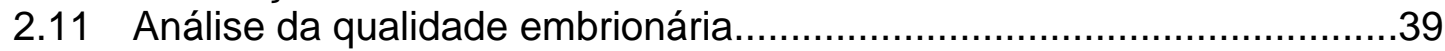

2.12 Expressão gênica: análise e sua importância....................................41

3 OBJETIVO

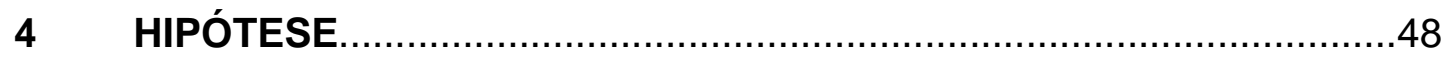

$5 \quad$ MATERIAL E MÉTODO

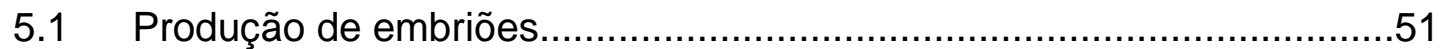

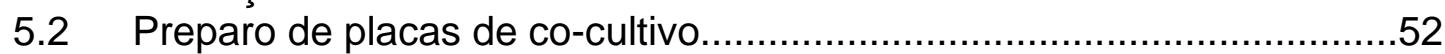

5.2.1 Placas de co-cultivo para produção de embriões................................52

5.2.2 Placas de co-culitivo para embriões criopreservados e descongelados.53

5.3 Exposição dos embriões aos crioprotetores........................................53

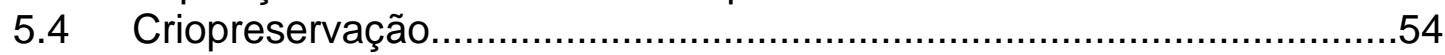

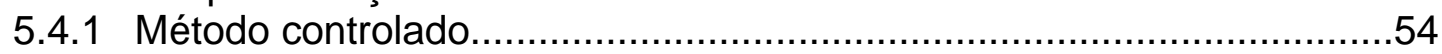

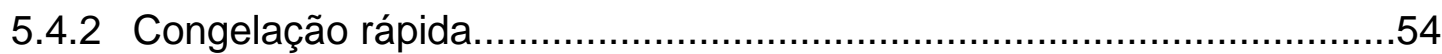

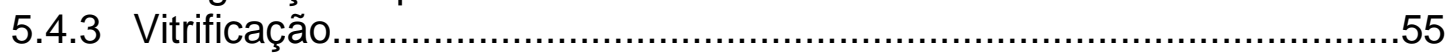

5.5 Descongelação dos embriões e remoção do crioprotetor......................55

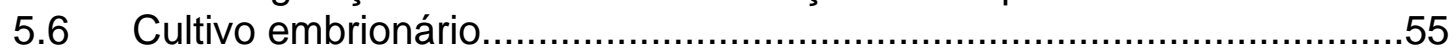

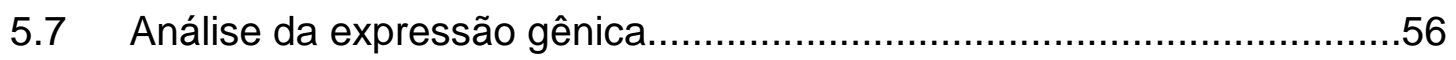

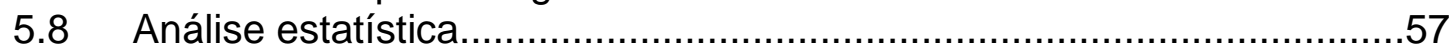

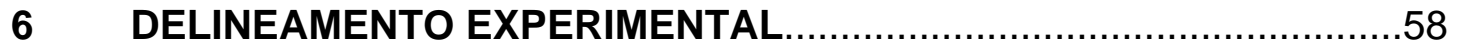

6.1 Experimento 1: Avaliação da sobrevivência dos embriões à exposição aos crioprotetores.........................................................................59 
6.2 Experimento 2: Avaliação da sobrevivência dos embriões à criopreservação............................................................................59

6.3 Experimento 3: Análise da expressão gênica em embriões criopreservados e frescos.............................................................60

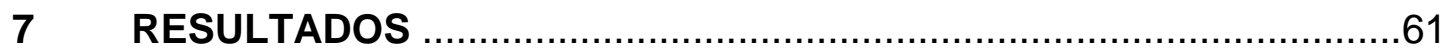

7.1 Experimento 1: Avaliação da sobrevivência dos embriões à exposição aos crioprotetores.............................................................................. 62

7.2 Experimento 2: Avaliação da sobrevivência dos embriões à criopreservação.........................................................................63

7.3 Experimento 3: Análise da expressão gênica em embriões criopreservados e frescos...............................................................65

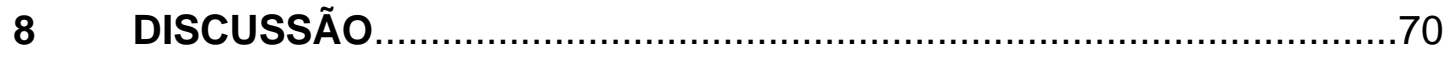

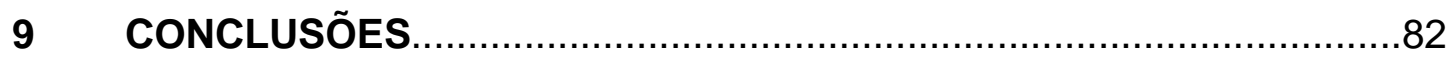

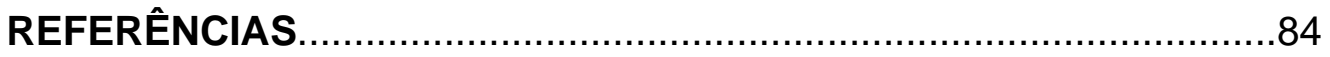

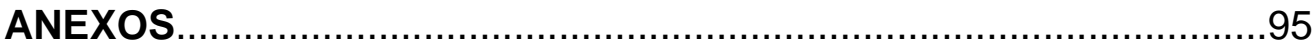




\section{INTRODUÇÃO}

A inseminação artificial, a transferência de embriões e a fecundação in vitro são biotécnicas reprodutivas que vêm incrementando a produção animal. Estas biotécnicas permitem a produção de grande número de embriões, sendo possível produzir 1,5 bezerros por semana por vaca com a fecundação in vitro ou 30 bezerros por vaca por ano com a transferência de embriões ou 1 bezerro por ano por vaca com a inseminação artificial. Entretanto, existem limitações, pois este grande número de embriões produzidos in vitro exige número compatível de receptoras para gestá-los. Assim, a criopreservação de embriões produzidos in vitro é uma facilidade para o manejo de embriões e receptoras.

Vários fatores influenciam a criopreservação de embriões como a composição dos meios de manutenção, os crioprotetores e as suas concentrações, o tempo de equilíbrio e de reidratação, a velocidade de resfriamento e aquecimento e as condições de cultivo.

Embriões produzidos in vivo e in vitro diferem em alguns aspectos quanto à morfologia, a velocidade de desenvolvimento, o metabolismo e a expressão gênica. Devido a estas diferenças, os embriões produzidos in vitro são mais sensíveis à congelação, portanto são necessárias adaptações das técnicas de congelação de embriões produzidos in vivo para embriões produzidos in vitro.

A viabilidade in vitro dos embriões após a criopreservação, avaliada pelos índices de eclosão, é uma das maneiras de estudar os efeitos da criopreservação de embriões, sendo muito empregada nestas pesquisas. Porém, da mesma maneira que o cultivo in vitro causa alterações morfológicas, metabólicas e moleculares antes da criopreservação, também causa alterações após a criopreservação. Portanto, analisar estes efeitos do cultivo após a criopreservação faz-se necessário para adaptar esta técnica, permitindo resultados mais precisos. 
Revisão de Literatura 


\section{REVISÃO DE LITERATURA}

\subsection{Panorama da produção in vitro de embriões}

Nos últimos trinta anos, a transferência de embriões vem crescendo e tornando-se uma indústria em que mais de 500.000 embriões são colhidos e transferidos ou criopreservados por ano. Atualmente, acima de $50 \%$ dos embriões são criopreservados (HASLER, 2001). Segundo dados publicados pela Sociedade Internacional de Transferência de Embriões (IETS), em 2003 foram transferidos 106.220 embriões produzidos in vitro no mundo, o que representa um aumento muito grande em relação aos anos anteriores, embora apenas uma pequena porcentagem de vacas receba embriões produzidos in vitro ao redor do mundo (HANSEN, 2006).

A produção in vitro de embriões bovinos a partir de oócitos imaturos é um procedimento de rotina em pesquisas de transgenia, clonagem e áreas relacionadas com a biologia da reprodução. Este recurso vem sendo utilizado comercialmente em programas de reprodução em gado (KRISHER; BAVISTER, 1998; KHURANA; NIEMANN, 2000a; BARD, et al., 2006).

Essa metodologia, incluindo a maturação e a fecundação de oócitos recuperados de pequenos $(3-5 \mathrm{~mm})$ e médios $(6-10 \mathrm{~mm})$ folículos, geralmente apresenta taxa de blastocisto em torno de 30 a 40\% (HYTTEL et al., 1997; MOHAN et al., 2002), sendo que após o cultivo in vitro apenas $50 \%$ dos embriões resultam em prenhezes após a transferência (MOHAN et al., 2002). Este sucesso limitado provavelmente deve-se à população heterogênea dos oócitos (HYTTEL et al., 1997).

Existem muitas razões para que a produção in vitro de embriões ainda não tenha realmente penetrado na indústria de produção de gado, sendo que parte destas razões não está diretamente relacionada com a técnica em si. Podemos citar como limitações ao emprego da técnica o alto custo de produção, condições subótimas de 
sobrevivência embrionária e fetal e, ocasionalmente, a ocorrência de anomalias nos animais produzidos (HANSEN, 2006).

\subsection{Desenvolvimento embrionário}

Muitos eventos importantes ocorrem durante o desenvolvimento embrionário desde a fase de zigoto até a formação do blastocisto. Isto inclui a primeira clivagem, que é uma fase crítica para determinar o desenvolvimento subseqüente do embrião; a ativação do genoma embrionário, no estágio entre 8 e 16 células; a compactação da mórula no dia 5, que envolve o estabelecimento do primeiro contato íntimo célula-célula do embrião e a formação do blastocisto entre os dias 6 e 7, que estabelece a diferenciação de dois tipos celulares, o trofectoderma e a massa celular interna (quando se trata de embriões bovinos) (LONERGAN et al., 2003).

O desenvolvimento pré-implantacional em mamíferos é caracterizado por três fases transitórias que ocorrem após a fecundação: a transição do controle genômico do oócito para o embrião, a compactação e a diferenciação da mórula para blastocisto (KANKA et al., 2003).

O desenvolvimento de oócitos fecundados requer a expressão orquestrada de genes específicos. Na maioria dos mamíferos, incluindo os bovinos, após a fecundação, o zigoto sofre várias clivagens, compactação e forma uma cavidade, originando o blastocisto e eclode (MOHAN et al., 2002; PONSUKSILI et al., 2002). Estes processos são regulados por diferenciadas expressões de importantes genes de desenvolvimento (PONSUKSILI et al., 2002). Estes eventos são mantidos inicialmente por transcritos e proteínas sintetizadas durante a oogênese (transcritos maternos), antes do estágio em que o genoma embrionário é ativado (MOHAN et al., 2002). A ativação do genoma embrionário é acompanhada por mudanças globais na expressão gênica, que é imposta pela formação de estados de repressão transcripcional (KANKA, et al., 2003). Na espécie bovina ocorre entre o estágio de 8 e 16 células (NATALE et al., 2001; MOHAN et al., 2002; KANKA et al., 2003). Existem ainda genes que são 
expressos no estágio de blastocisto e não no estágio de mórula e são funcionalmente candidatos a regular os processos que ocorrem na fase de diferenciação celular e implantação, um evento do desenvolvimento que tem grande porcentagem de mortalidade embrionária (PONSUKSILI et al., 2002). O desenvolvimento depende do sucesso em controlar os momentos temporal e espacial da expressão após a ativação do genoma embrionário (MOHAN et al., 2002). Claramente, qualquer modificação nas condições de cultivo pode afetar um ou todos estes processos, tendo efeito sobre a qualidade embrionária (RIZOS et al. 2003).

O desenvolvimento inicial de embriões pré-implantacionais em mamíferos é governado por genes transcritos e polipeptídios produzidos e estocados pelo oócito durante o seu desenvolvimento (HYTTEL et al., 2000; MOHAN et al., 2002). Entretanto, no decorrer das três primeiras clivagens, o controle do desenvolvimento é tomado pela expressão de porções do genoma embrionário, assim como os transcritos e as proteínas maternos são gradualmente degradados. Esta transição é um fenômeno gradual (HYTTEL et al., 2000).

Para o desenvolvimento adequado, um embrião precisa estar apto a ajustar sua fisiologia em resposta aos sinais regulatórios maternos ou outras mudanças no seu ambiente. Enquanto o progresso programado da ativação do genoma de embriões bovinos vem sendo estudado, pouco se sabe sobre, quando no desenvolvimento o genoma embrionário pode responder transcripcionalmente a sinais regulatórios ou perturbações no seu microambiente como calor, baixas de $\mathrm{pH}$, anoxia, entre outros fatores (CHANDOLIA et al., 1999).

Assim, foram encontrados estudos na literatura sobre o cultivo embrionário e suas influências. Estes estudos demonstraram que para cada estágio de desenvolvimento embrionário diferentes condições de cultivo como as proteínas dos meios de cultivo, concentração de $\mathrm{CO}_{2}$ e a presença/ausência de células do oviduto ou granulosa são necessários (SILVA; METELO, 2005). 


\subsection{Efeitos do cultivo in vitro sobre a qualidade embrionária}

Embora muitos progressos venham sendo feitos, os índices de produção de embriões ainda são baixos, ficando em torno de 10 a $20 \%$ dos oócitos submetidos ao processo de produção in vitro. Incrementar a eficiência e identificar variações nos sistemas de produção são, realmente, pontos importantes pois, comercialmente, estão sendo utilizados oócitos e espermatozóides oriundos de animais de grande mérito genético (MARQUANT-LEGUIENNE; HUMBLOT, 1998).

Entre todos os estágios envolvidos na produção in vitro de embriões, o cultivo embrionário é o que mais varia de toda a técnica e o que exerce maior efeito no desenvolvimento, morfologia e metabolismo, uma vez que os embriões permanecem neste meio por até oito dias (THOMPSON, 1997).

A produção in vitro expõe os embriões a uma grande variedade de estresses que normalmente não ocorrem no desenvolvimento in vivo. Em ruminantes, prolongados períodos de cultivo in vitro são associados com aumento da mortalidade fetal e dos riscos de anormalidades nos fetos. Mesmo com os mais eficientes sistemas de cultivo, grande proporção de zigotos apresenta falhas de desenvolvimento e diferentes padrões de expressão de importantes genes (FONTANIER-RAZZAQ et al., 2001).

Os sistemas de cultivo podem silenciar ou aumentar a expressão de um gene particular durante um momento crítico da fase de desenvolvimento. Um possível mecanismo é que as condições de cultivo alterem a taxa de degradação do RNAm, afetando a metilação e a expressão. Outra opção é que as condições de cultivo podem induzir a expressão de genes de morte celular, resultando em perdas embrionárias e fetais (NIEMANN; WRENZYCKI, 2000).

Estudos indicam que o cultivo de embriões em estágio pré-implantacional pode gerar modificações epigenéticas aberrantes nos genes. Após a transferência dos embriões cultivados in vitro, estas alterações podem ser mantidas somaticamente, 
podendo afetar a expressão gênica em estágios mais avançados de desenvolvimento pós-implantacional (KHOSLA et al., 2001).

Os efeitos deletérios do cultivo em condições subótimas são refletidos em modificações na expressão gênica dos embriões. Estes efeitos deletérios podem ser percebidos pela dificuldade dos embriões em serem criopreservados ou estabelecerem gestações ou, como vem sendo verificado em ruminantes, produzirem fetos de tamanhos anormais (LONERGAN et al., 2003).

Para contornar estes problemas e dificuldades pode-se melhorar a qualidade dos embriões com métodos apropriados de produção embrionária (VAJTA et al., 1999).

Uma grande variedade de sistemas de cultivo vem sendo utilizada para a produção de embriões in vitro, tanto com o propósito comercial quanto experimental (MARQUANT-LEGUIENNE; HUMBLOT, 1998).

Existem, essencialmente, dois sistemas de cultivo: co-cultivo e meios definidos (ou semidefinidos). O co-cultivo pode ser feito em meio TCM199 ou Menezo B2, comumente suplementado com soro, sendo o soro fetal bovino o mais usado. As células somáticas mais utilizadas são células da granulosa bovina, células epiteliais de oviduto bovino ou células BRL (buffalo rat liver). Sistemas de cultivo sem suporte de células somáticas são geralmente referidos como sistemas semidefinidos ou definidos, dependendo da presença de soro (ou proteínas) ou da suplementação com macromoléculas sintéticas. A principal diferença entre os sistemas definidos e o cocultivo é a concentração de cada componente maioritário conhecido antes da adição dos embriões (sem o uso do soro). Dentre os componentes adicionados aos meios para melhorar o desenvolvimento, a proteína (geralmente albumina sérica) e o soro parecem exercer a maior influência sobre o desenvolvimento embrionário, morfologia e metabolismo (THOMPSON, 1997).

Os efeitos benéficos do soro são vários como o suprimento de nutrientes, vitaminas, fatores de crescimento, hormônios e componentes antioxidantes. Porém, as atividades biológicas do soro variam conforme o lote, havendo risco de contaminação viral ou por micoplasma. Enquanto, o co-cultivo com células somáticas pareceu uma possibilidade de contornar a fase de bloqueio de embriões bovinos, seu preparo parece consumir mais tempo. Além disso, tanto o soro quanto o co-cultivo podem contribuir 
para alterações embrionárias na expressão gênica e no desenvolvimento fetal (HOSHI, 2003).

Embriões de ruminantes têm o desenvolvimento até o estágio de oito células semelhante, tanto in vivo quanto in vitro. Porém, a partir deste momento, que é quando ocorre a ativação do genoma embrionário, o desenvolvimento in vitro passa a ser mais lento. A adição de soro serve para contornar este problema, acelerando o desenvolvimento embrionário pré-compactação. Entretanto, o soro influencia, ainda, os níveis de apoptose, que pode ser determinante para o número de células e sua localização na massa celular interna e trofectoderma (THOMPSON, 1997).

A presença do soro nos meios de cultivo pode induzir ao acúmulo anormal de lipídeos. Como embriões bovinos com maior acúmulo de lipídeos são mais sensíveis a criopreservação, esta criosensibilidade de embriões bovinos produzidos in vitro na presença de soro pode ser alterada pela remoção do excesso de lipídeos (HOSHI, 2003).

Embriões bovinos pré-implantacionais podem se adaptar a uma enorme variedade de condições adversas ou inadequadas de cultivo. A exposição prolongada às condições in vitro provoca alterações substanciais nos padrões de expressão gênica, sendo a magnitude destas alterações dependentes da composição dos meios e das condições de cultivo. Estas alterações podem afetar o desenvolvimento embrionário e fetal (OLIVEIRA et al., 2005). E, ainda, o cultivo pode exercer efeito significativo sobre o metabolismo embrionário, alterando a qualidade embrionária (RIZOS et al., 2002).

Os meios de cultivo para produzir embriões não influenciam apenas o desenvolvimento embrionário, mas também a sobrevivência embrionária após a descongelação. Embora embriões produzidos in vitro tenham sido preservados pela congelação controlada ou, ainda pela vitrificação, a viabilidade embrionária varia muito conforme o protocolo de produção de embriões (NEDAMBALE et al., 2004).

Acredita-se que são as condições insuficientes de cultivo levam a tantas alterações nos embriões produzidos in vitro. Dessa forma, melhorar as condições de cultivo pode levar ao aumento dos índices de sobrevivência embrionária após a criopreservação (VAJTA, 1996). 
Porém, ainda há muito a ser descoberto sobre a relação entre os embriões pré-implantacionais e o ambiente (trato reprodutivo feminino ou meio de cultivo) para melhorar a qualidade de desenvolvimento dos embriões (KRISHER; BAVISTER, 1998).

\subsection{Diferenças entre embriões produzidos in vitro e in vivo}

Embriões produzidos in vitro diferem dos produzidos in vivo, apresentando citoplasma mais escuro e menos denso; blastômeros mais intumescidos; taxa de crescimento mais lento (FAIR et al., 2001); diferenças morfológicas, bioquímicas e metabólicas (NIEMANN; WRENZYCKI, 2000; MOHAN et al., 2002; LONERGAN et al., 2006) e maior sensibilidade a congelação, tendo menor habilidade para suportar a criopreservação (FAIR et al., 2001; LEONI, et al., 2002). E, ainda, apresentam zona pelúcida mais frágil e reduzida expressão de junções comunicantes intracelulares (LONERGAN et al., 2006). Além de taxas de prenhez significativamente menores do que os embriões produzidos in vivo (KHURANA; NIEMANN, 2000b; DOBRINSKY, 2002), além de alterações cromossômicas, baixos índices de prenhez após a transferência e aumento do peso dos bezerros (TESFAYE et al., 2003).

Estas diferenças são resultantes de condições subótimas de cultivo (TESFAYE et al., 2003) associado ao emprego de meios inadequados na produção in vitro e podem estar presentes em todos os estágios do desenvolvimento, desde a maturação oocitária até o nascimento do bezerro (VAJTA et al., 1997). Este fenômeno pode resultar em mudanças qualitativas e quantitativas no padrão de expressão gênica em comparação com embriões produzidos in vivo (TESFAYE et al., 2003). Embriões bovinos apresentam sensibilidade durante o desenvolvimento após a fecundação que se manifesta em termos de qualidade dos blastocistos (LONERGAN et al., 2003). Embriões pré-implantacionais mamíferos são mais sensíveis durante as primeiras clivagens, podendo as aberrações na expressão gênica no estágio de blastocisto ser reflexo de traumas do desenvolvimento inicial (GARDNER; LANE, 2005). 
Muitos estudos vêm indicando as alterações que o cultivo exerce sobre a qualidade dos embriões. Estudos têm comparado embriões produzidos in vitro e in vivo e vêm demonstrando inúmeras diferenças e alterações. As diferenças ultra-estruturais podem justificar a variação de criotolerância. Além disso, as diferenças de expressão gênica podem justificar a variação na qualidade (RIZOS et al., 2002).

Entre as muitas diferenças encontradas entre os embriões produzidos in vivo e in vitro que podem influenciar a sobrevivência após a criopreservação pode-se citar a demora na compactação dos blastômeros, alterações na expressão gênica e maior quantidade de lipídios dos embriões produzidos in vitro. Estas, por sua vez, podem contribuir para o aumento da sensibilidade térmica dos embriões produzidos in vitro em relação aos produzidos in vivo (PUGH; TERVIT; NIEMANN, 2000).

As taxas de prenhez com embriões produzidos in vitro e transferidos a fresco e de embriões produzidos in vivo e transferidos após a descongelação são semelhantes e constantes, ficando em torno de 60 a $70 \%$, enquanto que para embriões produzidos in vitro e criopreservados, estes valores são inconstantes e mais baixos (SOMMERFELD; NIEMANN, 1999).

\subsection{Criopreservação de embriões}

A criopreservação de embriões é de fundamental importância para facilitar a difusão do material genético superior dos animais em larga escala. Além disso, favorece o armazenamento dos embriões por longos períodos com reduzida perda da capacidade de desenvolvimento (KAIDI et al., 1999), permite o transporte do material genético pelo mundo, desenvolvimento de bancos de material genético de acasalamentos diferentes (FAHNING; GARCIA, 1992).

Assim, para maior flexibilidade, é essencial que os embriões possam ser estocados em nitrogênio líquido (KHURANA; NIEMANN, 2000a). O maior obstáculo para a utilização extensiva da produção in vitro de embriões bovinos com propósitos comerciais é a criopreservação (VAJTA et al., 1999). Vêm sendo relatados sucessos na 
criopreservação de embriões totalmente produzidos in vitro, resultando em prenhez e nascimento, assim como nos testes in vitro $\mathrm{e}$ in vivo de viabilidade após a descongelação (MASSIP et al., 1993). Entretanto, os resultados ainda são inconsistentes (LIEBERMANN et al., 2002).

Primeiramente, os embriões são expostos e equilibrados com o crioprotetor. Embriões expostos a crioprotetores permeáveis encolhem, perdendo água até atingirem um ponto de equilíbrio. Este encolhimento ocorre devido a uma hiperosmolaridade inicial da solução extracelular e ao fato dos embriões serem muito mais permeáveis a água do que aos crioprotetores. $\mathrm{O}$ encolhimento pára quando é atingido um equilíbrio entre a saída de água e a entrada de crioprotetor no embrião. Conforme os aditivos entram no embrião, este gradualmente re-expande porque ocorre entrada de água para manter o equilíbrio osmótico (FAHNING; GARCIA, 1992).

Uma das maneiras de solucionar o problema da criopreservação de embriões produzidos in vitro é encontrar um método ou protocolo mais adequado para estes embriões (VAJTA, 1996).

\subsection{Fatores que influenciam a criopreservação de embriões}

Extensas pesquisas a campo têm demonstrado que a criopreservação de embriões pode ser influenciada por muitos fatores, incluindo a espécie, o estágio embrionário, os crioprotetores (DOBRINSKY, 1996), a composição do meio de manutenção, o tempo de equilíbrio e rehidratação, as taxas de resfriamento e aquecimento e as condições de cultivo após a criopreservação (VAJTA et al., 1999). Assim como, a origem de produção destes embriões, pois embriões produzidos in vitro têm se mostrado mais sensíveis a criopreservação do que embriões produzidos in vivo (GEORGE; et al. 2006).

Tem sido relatado que a congelação e a descongelação diminuem a viabilidade embrionária, o que vem sendo atribuído aos danos físicos e químicos induzidos pelo processo. Estes danos podem ser conseqüência da ação tóxica dos 
crioprotetores que penetram as células durante o processo de solidificação. Esta injúria pode provocar a morte das células, afetando a viabilidade e o desenvolvimento embrionário (MARQUEZ-ALVARADO, 2004).

Podemos citar como fatores que influenciam a sobrevivência embrionária a concentração e composição dos crioprotetores, o procedimento de diluição do crioprotetor após a descongelação e as condições de congelação e descongelação (SILVA; METELO, 2005).

A melhor viabilidade de embriões ovinos e bovinos quando criopreservados em estágio de blastocisto expandido em comparação com o estágio de mórula provavelmente está relacionada ao aumento de sua tolerância ao processo após a formação da blastocele (LEONI et al., 2002).

Sabe-se que a zona pelúcida, após a fecundação, tem dupla função, atua no controle de patógenos e no transporte e difusão de nutrientes pelos seus poros. Portanto, a zona pelúcida pode favorecer ou prejudicar o crescimento e o desenvolvimento embrionário. Desta forma, quando as etapas da criopreservação causam danos à zona pelúcida, estes podem ser irreversíveis, prejudicando o posterior desenvolvimento embrionário (SILVA; METELO, 2005).

A origem dos embriões também exerce influência sobre os resultados. A criopreservação de embriões produzidos in vivo tem permitido alcançar taxas de prenhezes equivalentes às taxas de embriões frescos. Entretanto, os métodos empregados para embriões produzidos in vivo não se mostraram tão satisfatórios para embriões produzidos in vitro (LEIBO; LOSKUTOFF, 1993).

\subsection{Danos que a criopreservação pode causar aos embriões}

Grande parte das pesquisas em criobiologia está direcionada em entender os mecanismos de danos celulares durante a congelação e descongelação. Dessa forma, entende-se que existem dois mecanismos de danos celulares: químico, como 
conseqüência da desidratação das células; e físico, causado pela formação de cristais de gelo durante o processo (TAKAMATSU; RUBINSKY, 1999).

Muitos tipos de danos podem ainda ser citados como sendo causados pela criopreservação, incluindo o estresse de resfriamento, lesões causadas pelos cristais de gelo, estresse osmótico, efeito solução e estresse oxidativo (GEORGE et al., 2006).

A sensibilidade dos embriões produzidos in vitro está relacionada com vários fatores, como a estrutura da zona pelúcida, menor compactação das mórulas, sensibilidade ao resfriamento, aparência escura e aumento da densidade. Provavelmente, estas diferenças são causadas pela alta proporção lipídeos : proteínas que pode levar à formação de grande quantidade de gelo intracelular (VAJTA, 1996).

Pode-se verificar outros danos que a criopreservação causa aos embriões. Mudanças ultra-estruturais, assim como, danos aos microvilos da membrana plasmática, encolhimento das mitocôndrias, acúmulo de debris e diminuição dos contatos juncionais entre as células do trofoblasto são alguns exemplos (SILVA; METELO, 2005).

Pouco se sabe sobre as mudanças físicas que aparentemente acontecem após a congelação de embriões bovinos. Os crioprotetores podem causar toxicidade química e injúrias osmóticas às células embrionárias (SILVA; METELO, 2005).

Um fator essencial para a sobrevivência embrionária após a congelação é a penetração de crioprotetor no embrião, que pode aumentar com o tempo. Entretanto, a ação tóxica do crioprotetor pode ser exacerbada com este aumento de tempo de exposição. Portanto, o tempo ideal de exposição de cada solução deve ser ajustado em função da penetração e da toxicidade do crioprotetor (TACHIKAWA et al., 1993).

Existem estudos sobre o comportamento das soluções crioprotetoras. Durante a congelação de uma solução, a parte não congelada muda significativamente suas propriedades físico-químicas, tensão superficial e interfacial. Além disso, a estrutura da água e as interações soluto-água podem ser drasticamente alteradas e as macromoléculas podem ser forçadas a se unirem em interações mais prováveis. Os grupos hidrofóbicos interagem fracamente com a água adjacente, preferindo um ambiente não aquoso. A água adjacente aos grupos hidrofóbicos assume maior grau de estruturação do que a água pura, resultado de mudança termodinâmica não favorável 
com o decréscimo de entropia. Para minimizar esta ocorrência, os grupos hidrofóbicos tendem a agregar-se, diminuindo seu contato com a água, num processo chamado interação hidrofóbica. Muitos componentes celulares - em particular as proteínas, ácidos nucléicos e lipídeos polares - são anfipáticos e tendem a formar estruturas nas quais as partes hidrofóbicas não polares são escondidas da água (CANEIRO; CALVIDAL, 2000).

Estudos na área de criobiologia indicam que o mecanismo de dano durante a congelação com resfriamento lento é químico e relacionado com a hipertonicidade da solução extracelular durante a congelação. Entretanto, existem evidências de que o mecanismo de danos pode estar relacionado, pelo menos em parte, a danos mecânicos causados pela interação entre o gelo e as células. Este dano pode estar relacionado com a deformação das células pelos cristais de gelo formados (TAKAMATSU; RUBINSKY, 1999).

Durante o processo de resfriamento das células, acontecem danos devido à formação progressiva de cristais de gelo no meio externo, com conseqüente aumento da concentração de solutos não permeáveis no meio extracelular. Este dano causado pela solução extracelular hipertônica pode ser químico e relacionado com mudanças no volume celular induzido osmoticamente (TAKAMATSU; RUBINSKY, 1999).

Quando uma suspensão de células é congelada, há formação de cristais de gelo primeiro no meio extracelular, diminuindo gradualmente, a quantidade de água não congelada. Simultaneamente, durante o resfriamento, as células desidratam em função de forças osmóticas resultantes da concentração de solutos extracelulares devido a congelação. Se o resfriamento for lento, a solução intracelular vai, eventualmente, passar por uma transição de solidificação assumindo um estado não cristalino, podendo as células sofrer danos pelo chamado Efeito Solução. Se o resfriamento for rápido, a solução intracelular vai cristalizar com concomitante injúria celular. Para uma velocidade de resfriamento próxima do ótimo, a solução intracelular deve solidificar de maneira total ou parcialmente vítrea. Em último caso, o citoplasma compromete a matriz solidificada com gelo ou micro-cristais. Entretanto, existem muitos mecanismos de danos celulares durante o processo de descongelação também. As crioinjúrias durante o processo de descongelação são resultantes, em parte, da devitrificação da solução 
intracelular, ou seja, da formação de novos núcleos de cristais de gelo ou crescimento dos cristais já existentes (KARLSSON, 2001).

Carneiro e Cal-Vidal (2000), estudando a estruturação de cristais de gelo visando a criopreservação de frutos tropicais, classificaram dois mecanismos que podem promover dano à estrutura celular. O primeiro está relacionado com a possibilidade de perfuração da membrana celular pelo cristal de gelo intracelular. $O$ segundo se relaciona com a quebra da parede celular pelos cristais formados no meio extracelular. Podemos extrapolar este princípio de formação de cristais intra e extracelular para células animais e, conseqüentemente, para os embriões.

\subsection{Estratégias para evitar os danos embrionários durante a criopreservação}

A meta é evitar condições hiperosmóticas e formação intracelular de cristais de gelo, procurando adequar os processos de congelação e de descongelação na presença de crioprotetores (MASSIP et al., 1989).

As estratégias para contornar estas injúrias são bem diferentes, podendo ser o aumento da concentração da solução crioprotetora para prevenir a formação de cristais de gelo ou a diminuição da concentração da solução para reduzir o efeito tóxico (KASAI; ITO; EDASHIGE, 2002).

Uma possibilidade para contornar os problemas da criopreservação de embriões produzidos in vitro é ajustar os métodos de criopreservação para atender as necessidades destes embriões (VAJTA et al., 1999). Atualmente, existem duas vertentes de estudo para criopreservação de embriões. A primeira vertente consiste na congelação controlada (ou congelação lenta) que foi inicialmente estabelecida para embriões de camundongos e depois aplicada em embriões bovinos produzidos in vivo. A segunda vertente é a vitrificação que envolve a adição de altas concentrações de crioprotetores e taxas de congelação muito rápidas, evitando a formação de cristais de gelo (SILVA; METELO, 2005). Depois de muitas modificações na congelação 
controlada, a vitrificação tem se mostrado uma alternativa para este propósito (VAJTA et al., 1999).

Para aperfeiçoar as condições de criopreservação é essencial identificar os mecanismos das injúrias que cada protocolo provoca sobre os embriões. $\mathrm{Na}$ congelação controlada a maior causa de injúrias é a formação de cristais de gelo, enquanto na vitrificação o efeito tóxico das soluções crioprotetoras muito concentradas é o maior obstáculo (KASAI; ITO; EDASHIGE, 2002).

\subsection{Congelação controlada}

A congelação controlada tem produzido índices de prenhez em torno de 50 a $55 \%$ a campo para embriões produzidos in vivo (WALKER; CAMPOS-CHILLON; SEIDEL, 2006).

As técnicas de criopreservação envolvem: adição de crioprotetor; congelação do embrião com indução prévia da cristalização e estocagem em nitrogênio líquido; descongelação do embrião e remoção do crioprotetor. Estes métodos envolvem a penetração do crioprotetor em temperatura ambiente e a desidratação dos embriões durante o processo de resfriamento e congelação, antes da imersão em nitrogênio líquido (FAHNING; GARCIA, 1992).

O objetivo é retirar o máximo de água possível do embrião e, assim, prevenir a formação de gelo intracelular enquanto o citoplasma super-resfria antes de congelar. A indução da cristalização (seeding) induz a mudança de estado da água para gelo, o que leva a um aumento da concentração de sais na solução. Uma vez que o gelo se forma, os embriões congelam lentamente, permitindo a eles mudança de concentrações osmóticas (FAHNING; GARCIA, 1992).

A velocidade lenta de resfriamento empregada visa manter o delicado balanço entre vários fatores que podem causar danos como a formação de cristais de gelo, injúrias osmóticas, efeito tóxico dos crioprotetores, concentração intracelular de 
eletrólitos, injúrias do resfriamento, fratura da zona pelúcida e de embriões e alterações de organelas intracelulares, citoesqueleto e contatos célula-célula (VAJTA, 2000).

As taxas de resfriamento foram adequadas para a remoção da água intracelular do embrião, prevenindo as injúrias causadas pelos cristais de gelo, enquanto minimizava-se o estresse tóxico/osmótico da exposição dos embriões a altas concentrações de sais (CAMPOS-CHILLON et al., 2006).

Os protocolos de criopreservação foram desenvolvidos para prevenir a formação de cristais de gelo intracelulares. A primeira estratégia (congelação controlada) foi baseada no princípio da desidratação (CAMPOS-CHILLON et al., 2006), produzindo um encolhimento gradual do embrião devido a saída de água do meio intracelular, reduzindo o volume embrionário (FAHNING; GARCIA, 1992).

O protocolo mais usado envolve a exposição dos embriões à solução de $1,5 \mathrm{M}$ de etileno glicol, com ou sem $0,1 \mathrm{M}$ de sacarose. Os embriões são envasados em palhetas de $0,25 \mathrm{ml}$ e mantidos a $-6^{\circ} \mathrm{C}$ até a indução da cristalização. É feito, então, o resfriamento a uma velocidade em torno de $0,6^{\circ} \mathrm{C}$ por minuto até atingir a temperatura final ao redor de $-32^{\circ} \mathrm{C}$. As palhetas são imersas em nitrogênio líquido, onde permanecem armazenadas (WALKER; CAMPOS-CHILLON; SEIDEL, 2006). Embora os índices obtidos sejam aceitáveis e difíceis de superar em embriões produzidos in vivo (VAJTA, 2000) existem limitações do emprego desta técnica, como o custo do equipamento e a demora do processo (WALKER; CAMPOS-CHILLON; SEIDEL, 2006).

Enquanto estudos indicam que a congelação rápida pode ser benéfica para a sobrevivência de embriões bovinos produzidos in vitro (MAHMOUDZADEH et al., 1995). Mahmoudzadeh et al. (1994) sugerem que a baixa taxa de sobrevivência embrionária após a congelação controlada não é devido ao protocolo, mas sim a alta sensibilidade dos embriões produzidos in vitro ao processo. 


\subsection{Vitrificação}

Rall e Fahy (1985) introduziram a vitrificação como método para criopreservar embriões de mamíferos na ausência de gelo. Esta técnica reduz a necessidade de equipamentos e diminui o custo e o tempo por embrião transferido (DOBRINSKY, 2002).

A vitrificação pode ser definida como um processo físico, pelo qual uma solução muito concentrada de crioprotetor solidifica durante a congelação, sem formar cristais de gelo. A solução fica muito viscosa e assume um estado amorfo, denominado vítreo, que mantém a distribuição iônica e molecular do estado líquido (DARVELID et al., 1994). A vitrificação é caracterizada pela ausência total de cristais de gelo, tanto no meio intracelular quanto no meio extracelular (LIEBERMANN et al., 2002).

Os protocolos de congelação rápida e vitrificação são estratégias particularmente atrativas para criopreservar embriões porque são baratas, rápidas e simples, porém, as soluções crioprotetoras apresentam altas concentrações de crioprotetores, podendo ser tóxicas aos embriões. Assim, muitos esforços têm sido feitos para melhorar estes protocolos (KULESHOVA et al., 2001).

Esta estratégia, denominada vitrificação, requer soluções muito viscosas, taxas de resfriamento muito rápidas, pequenos volumes e soluções com altas concentrações de crioprotetores para alterar o estado físico da solução, tornando-o semelhante ao vidro (CAMPOS-CHILLON et al., 2006). A vitrificação é uma promessa, pois, não há formação de cristais de gelo e como o resfriamento é feito rapidamente, há menor dano pelo resfriamento (VAJTA, 1996).

A vitrificação requer altas concentrações de crioprotetores para atingir a conformação vítrea. O sucesso da vitrificação requer o estabelecimento das concentrações de crioprotetores, tempo e temperatura de exposição. Sendo que estas condições ainda não foram estabelecidas para embriões em estágio de mórula, pois 
neste estágio de desenvolvimento os embriões produzidos in vitro são mais sensíveis aos crioprotetores (CAMPOS-CHILLON et al., 2006).

As altas concentrações de crioprotetor podem causar injúrias tóxicas e osmóticas, sendo que a extensão desses danos depende da permeabilidade das soluções usadas e do estágio de desenvolvimento embrionário (VAJTA, 1996). O maior obstáculo para a vitrificação é a toxicidade das soluções crioprotetoras e depende não apenas da concentração dos componentes permeáveis, mas também do tempo e da temperatura de exposição (KASAl et al., 2002).

Existe uma questão a ser observada quando se estuda a vitrificação de embriões, que são as diferentes soluções crioprotetoras e os diferentes recipientes que vêm sendo empregados, dificultando o estabelecimento de um protocolo único. Entretanto, os relatos de prenhezes após a vitrificação de embriões encorajam os estudos desta técnica. É importante salientar, ainda, que os resultados ainda são inconsistentes (LIEBERMANN et al., 2002).

A criopreservação pela vitrificação parece ser mais adequada para embriões produzidos in vitro (KAIDI et al., 1999). O etileno glicol, por exemplo, é altamente permeável, quando usado em altas concentrações como exige a vitrificação ele é altamente tóxico. Por isso, recomenda-se a associação deste com outro crioprotetor (VAJTA, 1996). Assim sendo, vêm sendo utilizadas associações de crioprotetores como o glicerol (Gli) e propanodiol; o etileno glicol (EG), ficoll e sacarose; o etileno glicol (EG) e dimetilsulfóxido (DMSO); o etileno glicol (EG), trealose e polivinilpirrolidona; o glicerol (Gli) e etileno glicol (EG). Entretanto, as soluções de vitrificação contêm altas concentrações de crioprotetores que podem ser prejudiciais aos embriões (KAIDI et al., 1999).

Outra maneira de tentar minimizar os danos que as altas concentrações de crioprotetores podem causar é fazer a exposição em duas etapas. O primeiro passo desta exposição ao crioprotetor é feito com soluções menos concentradas para conseguir o equilíbrio entre os fluídos extra e intracelulares. O segundo passo é feito com soluções concentradas e tempos de exposição relativamente curtos, acompanhados pelo encolhimento do embrião e aumento de concentração de macromoléculas e de eletrólitos intracelulares (VAJTA, 1997). 
Vajta et al. (1996) ao estudarem a vitrificação de embriões produzidos in vitro em diferentes estágios de desenvolvimento relataram que os índices de re-expansão de blastocistos iniciais $(\mathrm{Bi})$, blastocistos $(\mathrm{Bl})$ e blastocistos expandidos $(\mathrm{Bx})$ não diferiram, entretanto, houve aumento dos índices de eclosão em estágios mais adiantados. Isso pode ser explicado por diferenças estruturais resultantes do decréscimo de sensibilidade a vitrificação e descongelação em estágios mais avançados.

A pré-congelação no vapor de nitrogênio antes da imersão em nitrogênio líquido reduz significativamente o rompimento das palhetas (RALL, 1987). Por outro lado isto muda a velocidade de resfriamento durante a vitrificação, podendo ser prejudicial às células embrionárias (DARVELID et al., 1994).

A vitrificação no vapor de nitrogênio é feita para prevenir fraturas que podem danificar o embrião ou a zona pelúcida. Estas fraturas têm sido observadas quando soluções muito concentradas são imersas abruptamente em nitrogênio líquido. Isto pode ser evitado pela congelação da solução em vapor de nitrogênio por dois minutos antes da imersão em nitrogênio líquido, o que permite a uniformidade de temperatura na amostra durante a congelação. Estudo publicado por Vajta et al. (1997a) mostrou que a fratura da zona pelúcida pode ocorrer por mudanças de pressão induzidas nas soluções pelo rápido encolhimento e expansão de bolhas de ar durante as mudanças de temperatura. Portanto, as condições ótimas de congelação e descongelação têm de ser encontradas para cada solução de vitrificação (DONNAY et al., 1998).

Comparações entre a congelação controlada e a vitrificação têm mostrado diferentes resultados, embora pareça que a vitrificação seja mais adequada para embriões produzidos in vitro (MUCCl et al., 2005). Nedambale et al. (2004), ao compararem a congelação controlada e a vitrificação, concluíram que a vitrificação apresentou melhores índices de sobrevivência embrionária in vitro para embriões produzidos em sistema de cultivo seqüencial de KSOM-SOF. Porém, os autores citam dados de embriões produzidos em co-cultivo que teriam apresentado alta sobrevivência após a congelação controlada (dados não publicados pelo grupo).

A maioria das publicações que compara a congelação controlada e a vitrificação apresenta resultados semelhantes de sobrevivência embrionária in vivo e in vitro ou ainda a vitrificação apresenta melhores resultados. Porém, quando se fala em 
embriões produzidos in vivo, a vitrificação não vem sendo aplicada. Existem algumas explicações para o fato, como os índices de congelação controlada para embriões produzidos in vivo estarem cerca de $10 \%$ a baixo dos índices obtidos com embriões frescos, sendo difícil superar. Além disso, existe uma diversidade de metodologias e protocolos de vitrificação muito grande, sem que haja uma técnica definitivamente eficiente a ser seguida. Isso sem dizer que a praticidade da técnica é relativa, pois, o tempo gasto para vitrificar um embrião é de cerca de 3 minutos. Porém, os embriões precisam ser tratados individualmente. Caso existam entre 15 e 25 embriões, o tempo total gasto é semelhante, sendo exercida a tarefa com mais demora (VAJTA, 2000). Outros autores salientam essa questão da praticidade relativa da vitrificação, sendo este fato verdadeiro apenas para grupos reduzidos de embriões (VAN WAGTENDONKDE LEEUW; et al., 1995).

Outro ponto importante a ser considerado é que as condições experimentais variam muito entre os trabalhos, havendo várias alternativas de métodos e protocolos de criopreservação, dificultando a comparação entre índices de prenhez dos diferentes trabalhos publicados (VAN WAGTENDONK-DE LEEUW; et al., 1995).

\subsection{Análise da qualidade embrionária}

A avaliação dos embriões antes da transferência é importante para o sucesso dos programas de transferência de embriões (HOSHI, 2003). O tempo de desenvolvimento é um bom indicativo da competência de sobrevivência embrionária (THOMPSON, 1997). É importante ressaltar que apenas o desenvolvimento de blastocistos tem sido usado, em vários laboratórios, como parâmetro para avaliar o sistema de cultivo (RUSSELL et al., 2006).

Embora a avaliação morfológica dos embriões seja bastante útil para predizer os índices de prenhez, esta não é tão eficiente para predizer a sobrevivência de embriões individualmente (HOSHI, 2003) e, nem mesmo, é uma maneira eficiente de predizer a habilidade destes embriões em originarem crias saudáveis (RUSSELL et al., 
2006). Há embriões classificados morfologicamente como de qualidade ruim que conseguem resultar em prenhezes, enquanto que embriões classificados morfologicamente como de qualidade excelente não resultam em prenhezes. Estes relatos sugerem que, além da avaliação morfológica, é necessário encontrar uma maneira mais precisa para avaliar a viabilidade embrionária (HOSHI, 2003; RUSSELL et al., 2006).

Em estudos mais recentes, quando a relação entre a morfologia embrionária, a ultra-estrutura, a expressão gênica e a criotolerância vem sendo feita, muito tem sido atribuído à análise morfológica dos embriões, trazendo novamente a atenção dos pesquisadores para os aspectos morfológicos. Dessa forma, a coloração dos blastômeros, a extensão da compactação, a cinética do desenvolvimento e o tempo para a formação da blastocele e o diâmetro do embrião no momento da eclosão vem sendo relacionados com a qualidade embrionária (LONERGAN; et al., 2006). $\mathrm{Na}$ realidade, o ideal é utilizar uma combinação de fatores para avaliar a qualidade embrionária, como o número de células e sua localização no embrião, a ocorrência de apoptose e a expressão de determinados genes (RUSSELL et al., 2006).

Enquanto a qualidade do oócito é o principal determinante do desenvolvimento embrionário inicial, o sistema de cultivo após a fecundação é o principal fator que influencia a qualidade destes embriões. Há vários estudos sobre sistemas de cultivo que verificam o número de blastocistos e não a qualidade dos embriões. Assim, métodos para avaliar a qualidade dos embriões como a contagem de células, a criotolerância e o padrão de expressão gênica devem ser associados com as mensurações de desenvolvimento embrionário para comparar os diferentes sistemas de cultivo (PEREIRA; DODE; RUMPF, 2005).

Na produção in vitro de embriões, qualquer resposta do sistema de produção que cause danos ao DNA e que possa ser detectada precocemente será de grande valor para selecionar o sistema de cultivo que apresenta menor risco de induzir a expressão gênica aberrante (FONTANIER-RAZZAQ et al., 2001).

Para adaptar os protocolos de criopreservação é necessário um procedimento simples e acurado para avaliar a viabilidade embrionária após a descongelação. O melhor critério é o nascimento de animais saudáveis (KAIDI et al., 
1998), avaliando-se os índices de prenhez e nascimentos, duração da gestação, peso e proporção entre machos e fêmeas ao nascimento (MARTINEZ et al., 2002). Entretanto, muitos fatores influenciam a manutenção da prenhez após a transferência de embriões produzidos in vitro como o sistema de cultivo utilizado na produção, qualidade embrionária, número de embriões transferidos por receptora, sincronia entre o embrião e a receptora, profissional que executou a transferência, embriões frescos ou criopreservados e, ainda, efeito de estresse térmico sobre os embriões e/ou as receptoras (LIM et al., 2007). Assim, alternativas podem ser utilizadas como a avaliação da re-expansão e eclosão in vitro, a avaliação do número total de células, trofectoderma e massa celular interna ou os estudos metabólicos (KAIDI et al., 1998; MARTINEZ et al., 2002).

A habilidade de criopreservação depende da qualidade dos embriões e das condições de cultivo que pode, porém, ser melhorada pelo ajuste do procedimento de criopreservação (KAIDI et al., 1998). Além disso, um bom indicativo do potencial de sobrevivência in vivo dos embriões descongelados pode ser o desenvolvimento in vitro com taxas equivalentes aos embriões não criopreservados (PUGH; TERVIT; NIEMANN, 2000). A viabilidade dos embriões pós-descongelação pode ser verificada por diferentes métodos, o mais comum é o cultivo por 24 ou 48 horas. Além disso, os embriões após a descongelação devem ser co-cultivados com células da granulosa (RIZOS et al., 2001). Entretanto, a correlação entre a taxa de prenhez e a sobrevivência in vitro dos embriões é considerada baixa (KAIDI et al., 1999). As condições de co-cultivo podem influenciar a sobrevivência e a qualidade dos blastocistos após a criopreservação também (KAIDI et al., 1998).

\subsection{Expressão gênica: análise e sua importância}

Aproximadamente 10.000 genes precisam ser expressos para que se tenha uma orquestrada regulação do desenvolvimento embrionário pré e pós-implantacional (NIEMANN; WRENZYCKI, 2000; MOHAN et al., 2002). Entretanto, até o momento, 
apenas 15 funções fisiológicas e a expressão de 60 a 70 genes foram bem estudados (NIEMANN; WRENZYCKI, 2000; TESFAYE et al., 2005).

Durante o período pré-implantacional, o embrião passa por uma série de eventos de desenvolvimento morfo-genéticos incluindo a maturação do oócito, a ativação do genoma embrionário quando ocorre a transição do controle de transcrição de materno para fetal. O efeito de alterações no padrão de expressão gênica em embriões bovinos produzidos in vitro, principalmente quando cultivados em condições subótimas, aparece refletido em importantes fenômenos como a Síndrome do Feto Gigante (LOS) (BADR et al., 2007).

A aplicação de ferramentas moleculares para avaliar embriões em estágios pré-implantacionais nos animais de produção podem trazer novos conhecimentos sobre o desenvolvimento embrionário de mamíferos, ajudando a incrementar os procedimentos de biotecnologia (KANKA et al., 2003).

A expressão gênica embrionária pode ser alterada em resposta ao estresse ambiental, o que provavelmente é uma maneira do embrião estabilizar sua função celular. Isto será muito útil para determinar como o padrão de expressão gênica do embrião pode ser alterado por outros sinais de origem materna ou embrionária que podem coordenar o desenvolvimento embrionário com as progressivas mudanças no trato reprodutivo feminino durante a gestação (CHANDOLIA et al., 1999).

Tipos de RNAm oriundos de diferentes sistemas de cultivo ou de embriões produzidos in vitro ou in vivo não são necessariamente os mesmos. Alterações encontradas na expressão de RNAm podem estar diretamente ligadas à qualidade embrionária (KANKA et al., 2003).

Diferentes condições de cultivo afetam a expressão gênica em embriões mamíferos, sendo a dinâmica do RNAm útil para aperfeiçoar as condições de cultivo in vitro (STOJKOVIC et al., 2003; BADR et al., 2007).

A análise das diferenças nas expressões de RNAm pode explicar as diferenças observadas na criotolerância entre embriões produzidos in vitro e in vivo e pode propiciar a oportunidade de modificar a expressão gênica e o sistema de cultivo para melhorar a viabilidade pós-descongelação (RIZOS et al., 2002; RIZOS et al., 2003). 
O melhor conhecimento do padrão de expressão gênica durante o período de desenvolvimento pré-implantacional permitirá aumento do conhecimento de padrões moleculares que controlam o desenvolvimento inicial e, ainda, um preâmbulo para entender eventos que podem resultar em mortalidade embrionária precoce (MOHAN et al., 2002).

A análise da expressão gênica de embriões pode ser o procedimento de escolha para avaliar a qualidade embrionária no futuro. Entretanto, ainda existem problemas, como a definição de genes a serem estudados e quanto do gene pode ser expresso em uma célula normal (YUAN et al., 2003).

Estratégias de análise de expressão gênica vêm sendo introduzidas com sucesso no estudo qualitativo e quantitativo da transcrição gênica que ocorre durante a maturação oocitária e o desenvolvimento embrionário (LECHNIAK, 2002).

Graças ao progresso da tecnologia molecular, está se conhecendo maior número de genes expressos durante o desenvolvimento embrionário (KANKA et al., 2003). Os tipos de RNAm servem como importante ferramenta para verificar a normalidade de embriões e aperfeiçoar as condições de cultivo in vitro (NIEMANN; WRENZYCKI, 2000; KANKA et al., 2003).

Além dos métodos como Differential Display (DD) RNAm, bibliotecas de cDNA substrativo, quantitativo e real-time RT-PCR, existem metodologias como os microarrays para identificar diferentes RNAm (KANKA et al., 2003). A Differential Display-RT-PCR (DD-RT-PCR) permite a identificação de novos genes sem que se conheçam suas seqüências (NIEMANN; WRENZYCKI, 2000) e vem sendo aplicada para comparar padrões de expressão de RNAm em embriões na fase préimplantacional (MOHAN et al., 2002), sendo um valioso método para comparar pools de RNAm entre duas ou mais amostras e ainda permite avaliar a influência do sistema de cultivo sobre a expressão gênica (NATALE et al., 2001).

O uso de técnicas como a DD-RT-PCR permite a comparação do padrão de expressão de RNAm entre amostras, permitindo identificar novos e raros transcritos. Devido à necessidade de pouco material para executar esta técnica, seu uso em oócitos e embriões vem permitindo a identificação de genes específicos (TESFAYE et al., 2003). 
Novos genes críticos para o desenvolvimento podem potencialmente ser identificados, usando DD RNAm ou bibliotecas de cDNA substrativo. O uso de ferramentas moleculares avançadas abre novos horizontes para a pesquisa e incrementam significativamente os conhecimentos básicos do desenvolvimento embrionário, assim como contribuem para a melhoria de vários procedimentos biotecnológicos envolvendo oócitos e embriões (NIEMANN; WRENZYCKI, 2000) e esclarecem o processo de ativação do genoma embrionário em bovinos (KANKA et al., 2003).

A análise da expressão gênica embrionária pela técnica de DD-RT-PCR vem sendo muita aplicada, pois permite identificar respostas genéticas a estímulos específicos, embora tenha seu uso restrito por permitir a amplificação de uma pequena porção do genoma total. Além disso, esta técnica é muito sensível e leva a falsos positivos, o que exige outras análises quantitativas que comprovem os resultados, como a análise por PCR em Tempo Real (LIM et al., 2007).

Lonergan et al. (2003) selecionaram alguns genes relacionados a importantes processos fisiológicos como o transporte e o metabolismo de frutose (GLUT-5), o estresse (SOX), a atividade mitocondrial e detoxificação de espécies reativas a oxigênio (MnSOD), a comunicação celular (Cx43), o reconhecimento materno de prenhez (ITN- $\tau$ ), a apoptose (Bax), o ligante do fator de crescimento (EGF-IR) e o metabolismo e estresse oxidativo (G6PD).

O sistema de cultivo pode afetar o desenvolvimento e a qualidade dos blastocistos e a criotolerância pode ser um bom indicador da qualidade dos embriões (RIZOS et al., 2001; DOBRINSKY, 2002; CAMPOS-CHILLON et al., 2006). Os embriões bovinos produzidos in vitro apresentam significativa diferença de sobrevivência após a criopreservação (ENRIGHT et al., 2000; SILVA; METELO, 2005), pois são mais sensíveis às injúrias decorrentes dos efeitos tóxicos e osmóticos dos crioprotetores, assim como à formação de cristais de gelo (VAJTA; HYTTEL; CALLESEN, 1997). A reduzida criotolerância dos blastocistos produzidos in vitro na presença de soro é acompanhada por desvios na relativa abundância de transcritos de importantes genes do desenvolvimento (RIZOS et al., 2003). 
Dentre os muitos estudos que vêm sendo realizados, pode-se encontrar duas vertentes, ou seja, trabalhos sobre o desenvolvimento de novos protocolos de criopreservação e seus efeitos e trabalhos sobre o cultivo embrionário, visando melhorar a qualidade dos embriões para suportarem os processos de criopreservação (MARTINEZ et al., 2002; MUCCl et al., 2005). 
3 OBJETIVO

Este estudo teve como objetivo identificar os danos causados pela criopreservação e pelo cultivo de embriões bovinos produzidos in vitro após a descongelação, avaliando a morfologia, a expressão gênica e o desenvolvimento in vitro antes e após a criopreservação. 
Hipótese 


\section{HIPÓTESE}

A criopreservação causa danos ao DNA embrionário, prejudicando a expressão gênica, o que inviabiliza o desenvolvimento embrionário in vitro após a descongelação e cultivo in vitro. E o cultivo embrionário in vitro após a criopreservação causa alterações na expressão gênica o que dificulta relacionar os resultados obtidos in vitro com os in vivo. 
Material e Método 


\section{MATERIAL E MÉTODO}

Foram utilizados ovários bovinos oriundos de abatedouros para obtenção de oócitos, os quais foram maturados, fecundados e cultivados in vitro. Os embriões produzidos nestes procedimentos foram criopreservados ou não conforme o grupo experimental.

\subsection{Produção de embriões bovinos}

Foram colhidos ovários bovinos em matadouro e transportados em solução salina, com temperatura controlada $\left(30\right.$ a $\left.33^{\circ} \mathrm{C}\right)$ até o laboratório. Os ovários foram lavados em solução salina e mantidos em banho-maria à $30^{\circ} \mathrm{C}$. Os folículos foram aspirados com seringa de $5 \mathrm{ml}$ e agulha $25 \times 8$ (21G) e o líquido folicular mantido em tubo de $15 \mathrm{ml}$ em banho-maria a $30^{\circ} \mathrm{C}$ por 10 minutos. $O$ sedimento foi examinado sob estereomicroscópio, em placa de petri, para localização e seleção dos oócitos.

Os oócitos com citoplasma de coloração homogênea e mais de duas camadas completas de células do cummulus foram lavados em meio de lavagem (Anexo B.1) e em meio de maturação (Anexo B.2) e colocados para maturar in vitro (MIV) em microgotas de 90 $\mu$ do meio de maturação (Anexo B.2) sob óleo mineral, por 24 horas, em estufa com $5 \% \mathrm{CO}_{2}$ em ar; $38,5^{\circ} \mathrm{C}$ e alta umidade. Foram colocados entre 10 e 30 oócitos por gota, sendo este padrão mantido em todo o processo.

Para a fecundação in vitro dos oócitos, o sêmen foi descongelado em banhomaria à $37^{\circ} \mathrm{C}$ por 30 segundos e centrifugado em gradiente de Percoll (Anexos B.6 e B.7) por 30 minutos a $700 \mathrm{~g}$ (Labofuge 300 Heraeus) para separação dos espermatozóides vivos e mortos. O sedimento foi ressuspendido, sendo novamente centrifugado por 5 minutos a $300 \mathrm{~g}$ em meio de fecundação (Anexo B.4). A 
concentração foi corrigida para $1 \times 10^{6}$ espermatozóides por $\mathrm{ml}$ do meio de fecundação. Os oócitos maturados foram lavados no meio de lavagem (Anexo B.3) e no meio de fecundação acrescido de agentes capacitores (Anexo B.5) e incubados em microgotas de $90 \mu \mathrm{l}$ de meio de fecundação (Anexo B.5) sob óleo mineral, onde foram acrescentados os espermatozóides. As placas de petri foram mantidas em estufa com $5 \%$ de $\mathrm{CO}_{2}$ em ar; $38,5^{\circ} \mathrm{C}$ e alta umidade.

Após 18 horas da fecundação, os prováveis zigotos foram co-cultivados (Anexo B.8), após remoção mecânica das células do cumulus. Após 48 horas de cultivo foi acrescido $90 \mu \mathrm{l}$ do meio de cultivo (Anexo B.8) às microgotas (feeding) e avaliada a clivagem. Os embriões foram avaliados a partir do sétimo dia da fecundação. Como controle, uma gota por placa foi mantida sem que os embriões recebessem qualquer tratamento para avaliar a eclosão.

\subsection{Preparo das placas de co-cultivo}

As placas para o co-cultivo dos presumíveis zigotos e embriões foram preparadas conforme a descrição a seguir.

\subsubsection{Placas de co-cultivo para produção de embriões}

Após a maturação, os oócitos foram retirados das placas para a fecundação. Para a formação da monocamada de células da granulosa, o meio de maturação foi retirado, as gotas lavadas com $50 \mu$ de meio de cultivo, que foram descartados e colocados $90 \mu \mathrm{l}$ de meio de cultivo por gota. No dia seguinte, os prováveis zigotos foram transferidos para estas placas. 


\subsubsection{Placas de co-culitivo para embriões criopreservados e descongelados}

Grupos de 5 a 10 oócitos (com menos de duas camadas de células do cummulus completas) foram lavados em meio de lavagem e em meio de maturação e colocados em microgotas de $90 \mu \mathrm{l}$ do meio de maturação sob óleo mineral e mantidos por 24 horas, em estufa com $5 \% \mathrm{CO}_{2}$ em ar; $38,5^{\circ} \mathrm{C}$ e alta umidade. Os oócitos foram retirados das gotas e descartados. Para a formação da monocamada de células da granulosa, o meio de maturação foi retirado, as gotas lavadas com $50 \mu \mathrm{l}$ de meio de cultivo, que foram descartados e colocados $90 \mu \mathrm{l}$ de meio de cultivo por gota. Após 3 dias foi acrescido $90 \mu \mathrm{l}$ do meio de cultivo a cada gota. Após 6 dias, estas placas receberam os embriões descongelados.

\subsection{Exposição dos embriões aos crioprotetores}

Os embriões foram expostos por 10 minutos à solução de $10 \%$ Etileno Glicol (EG) (Anexo 4.1) ou às soluções de $10 \%$ de $E G$ (Anexo C.3) e de $20 \% E G+20 \%$ de Glicerol (Anexo C.4) por 30 segundos. Em seguida foi feita a remoção do crioprotetor dos embriões em duas etapas, sendo lavados em $0,5 \mathrm{ml}$ da solução de PBS; 0,3M de Sacarose e 0,2\% de BSA (Anexo C.2) e em 0,5ml da solução de PBS e 0,2\% de BSA (Anexo C.1), ambas por 3 minutos. Os embriões foram recolocados na placa de cocultivo para avaliação da eclosão. 


\subsection{Criopreservação dos embriões}

Os embriões foram envasados em grupos de até 10 por palheta de $0,25 \mathrm{ml}$, preenchendo as colunas das extremidades (cerca de 4cm) com PBS; 0,3M de Sacarose e $0,2 \%$ de BSA (Anexo C.2), duas colunas com ar (cerca de $1 \mathrm{~cm}$ ) para separar as colunas das extremidades da coluna central (cerca de $1 \mathrm{~cm}$ ) preenchida com embriões e solução crioprotetora de acordo com o grupo experimental: controlado, rápido ou vitrificação.

\subsubsection{Método controlado}

Os embriões foram expostos por 10 minutos à solução de $10 \%$ de $E G$ (Anexo C.3), incluindo o tempo de envase. As palhetas foram lacradas e imersas em álcool a $7^{\circ} \mathrm{C}$ na máquina de congelação $(\mathrm{HAAKE} \otimes)$ por 5 minutos para equilíbrio da temperatura. Em seguida, foi induzida a cristalização (seeding) e, após 5 minutos, iniciado o resfriamento na velocidade de $1,2^{\circ} \mathrm{C}$ por minuto. Ao alcançar a temperatura de $-31^{\circ} \mathrm{C}$, aguardaram-se 10 minutos e as palhetas foram imersas e armazenadas em nitrogênio líquido.

\subsubsection{Congelação rápida}

Os embriões foram inicialmente equilibrados à solução de $10 \%$ de EG (Anexo C.3) por 10 minutos e depois à solução de $20 \%$ EG $+20 \%$ de Glicerol (Anexo C.4) por 30 segundos, incluindo o tempo de envase. As palhetas foram lacradas e 
colocadas em vapor de Nitrogênio (cerca de $0,8 \mathrm{~cm}$ da coluna de Nitrogênio Líquido à aproximadamente $-170^{\circ} \mathrm{C}$ ) por 2 minutos, imersas e armazenadas em Nitrogênio Líquido.

\subsubsection{Vitrificação}

Os embriões foram expostos à solução de $10 \%$ de EG (Anexo C.2) por 10 minutos e depois à solução de $25 \%$ de $E G+25 \%$ de Gli (Anexo C 5 ) por 30 segundos, incluindo o envase. As palhetas foram lacradas e colocadas em vapor de Nitrogênio (cerca de $0,8 \mathrm{~cm}$ da coluna de Nitrogênio Líquido à aproximadamente $-170^{\circ} \mathrm{C}$ ) por 2 minutos, imersas e armazenadas em Nitrogênio Líquido.

\subsection{Descongelação dos embriões e remoção do crioprotetor}

Os embriões foram descongelados por 10 segundos no ar e 20 segundos no banho-maria a $25^{\circ} \mathrm{C}$. Para a remoção do crioprotetor, os embriões foram colocados em 0,5ml da solução de PBS; 0,3M de Sacarose e 0,2\% de BSA (Anexo C.1) e em 0,5ml da solução de PBS e 0,2\% de BSA (Anexo C.2), ambas por 3 minutos.

\subsection{Cultivo embrionário}

Os embriões frescos, expostos aos crioprotetores e criopreservados foram co-cultivados in vitro no meio SOFaa (Anexo B.8) ou no meio TCM199 (Anexo B.9), ambos os meios com células da granulosa em estufa com $5 \%$ de $\mathrm{CO}_{2} \mathrm{em}$ ar; $38,5^{\circ} \mathrm{C}$ e alta umidade. Os embriões descongelados foram avaliados às 24 horas para verificar a 
taxa de re-expansão e às 48, 72 e 96 horas para as taxas de eclosão de todos os grupos.

\subsection{Análise da expressão gênica}

A extração de RNA total foi feita, a partir de 20 blastocistos expandidos frescos e 20 blastocistos expandidos criopreservados pelo método controlado, ambos cultivados em TCM199 por 24 horas. Destes blastocistos foi extraído o RNA total com o kit illustra RNAspin Mini RNA Isolation (GE Healthcare ${ }^{\circledR}$ ), seguindo orientações do fabricante e diluído em $30 \mu l$ de água livre de RNAses.

A síntese do DNA complementar (cDNA) foi feita com o RNA total extraído na etapa anterior, utilizando $1 \mu$ l de Superscript III (Invitrogen $®)(200 U / \mu l), 1 \mu$ de primer âncora 5' - AAT ACG ACT CAC TAT AGT (T) ${ }_{12} \mathrm{NN}$ - 3'(NN= GC, GA ou GG) $(5 \mu \mathrm{M}), 2 \mu \mathrm{l}$ de dNTPs (2,5mM cada), $2 \mu$ de DTT $(0,1 \mathrm{~m}), 1 \mu \mathrm{l}$ de RNaseOUT ${ }^{\circledR}\left(40 \mathrm{U} / \mu \mathrm{l}\right.$; Invitrogen $\left.{ }^{\circledR}\right)$ e $4 \mu \mathrm{l}$ de tampão 5X. Inicialmente, foram mantidos apenas o RNA e o primer âncora em termociclador (Mastercycler gradient - Eppendorf $\AA$ ) a $70^{\circ} \mathrm{C}$ por 5 minutos e a seguir a $4^{\circ} \mathrm{C}$ por 5 minutos. Foi adicionado $10 \mu \mathrm{l}$ de mix (preparado previamente e mantido a $20^{\circ} \mathrm{C}$ ) com o restante dos componentes e as reações foram realizadas a $42^{\circ} \mathrm{C}$ por 15 minutos, $50^{\circ} \mathrm{C}$ por 50 minutos e $70^{\circ} \mathrm{C}$ por 15 minutos para inativação da enzima (em termociclador Mastercycler gradient - Eppendorf $®)$.

As amplificações foram realizadas em 2 etapas, sendo a primeira com 10 ciclos contendo $1,33 \mu$ de produtos de RT-PCR (equivalente a 15pg de RNAm inicial), $1 \mu \mathrm{l}$ de tampão 10X, $2 \mu \mathrm{l}$ de dNTPs $(2.5 \mathrm{mM}$ cada), $1.33 \mu \mathrm{l}$ de TAMRA T7 $(5 \mu \mathrm{M}), 1.33 \mu \mathrm{l}$ de primer arbitrário $(5 \mu \mathrm{M}), 0.1 \mu \mathrm{l}$ de Taq DNA polimerase $\left(5 \mathrm{U} / \mu \mathrm{l}\right.$; Invitrogen $\left.{ }^{\circledR}\right)$ e $0.2 \mu \mathrm{l}$ de $\mathrm{MgCl}_{2}(50 \mathrm{mM})$. As condições de PCR foram de $95^{\circ} \mathrm{C}$ por 2 minutos, seguido por 10 ciclos de $92^{\circ} \mathrm{C}$ por 15 segundos, $42^{\circ} \mathrm{C}$ por 30 segundos e $72^{\circ} \mathrm{C}$ por 2 minutos, extensão final de $72^{\circ} \mathrm{C}$ por 10 minutos (em termociclador Mastercycler gradient - Eppendorf $\AA$ ). $A$ seguir, $10 \mu \mathrm{l}$ de mix contendo $1.8 \mu \mathrm{l}$ de $\mathrm{MgCl}_{2}(50 \mathrm{mM})$ e igual quantidade dos outros componentes foram adicionados para uma segunda etapa de amplificação de 25 ciclos 
de $92^{\circ} \mathrm{C}$ por 15 segundos, $42^{\circ} \mathrm{C}$ por 30 segundos e $72^{\circ} \mathrm{C}$ por 2 minutos e extensão final de $72^{\circ} \mathrm{C}$ por 10 minutos (em termociclador Mastercycler gradient - Eppendorf $\circledast$ ). Foram utilizados 3 primers âncoras e 10 primers arbitrários (RIPAMONTE, 2005).

Para verificar a eficiência da reação e quantificar a quantidade de produtos iniciais e finais, foi realizada reação de PCR em Tempo Real com primer para o gene GAPDH suíno e cDNA de 30 embriões suínos frescos (controle positivo) e produtos das reações de RT-PCR com 3 primers âncora e os grupos fresco e congelado. As reações

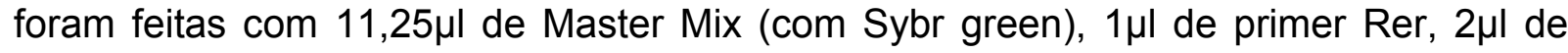
primer For, $2 \mu l$ de cDNA e $8,75 \mu l$ de água.

\subsection{Análise estatística}

A análise dos dados foi realizada com auxílio do Software Statistical Analysis Sistem for Windows $S A S \circledR$. As variáveis dependentes foram expressas em média e erro padrão da média (média \pm EPM) e analisados por ANOVA, usando o aplicativo PROC MIXED do $S A S \circledR$. Foram consideradas variáveis dependentes as porcentagens de reexpansão e de eclosão e como variáveis independentes os tratamentos (métodos de criopreservação), as réplicas e as gotas. 
Delineamento Experimental 


\section{DELINEAMENTO EXPERIMENTAL}

6.1 Experimento 1: Avaliação da sobrevivência dos embriões à exposição aos crioprotetores

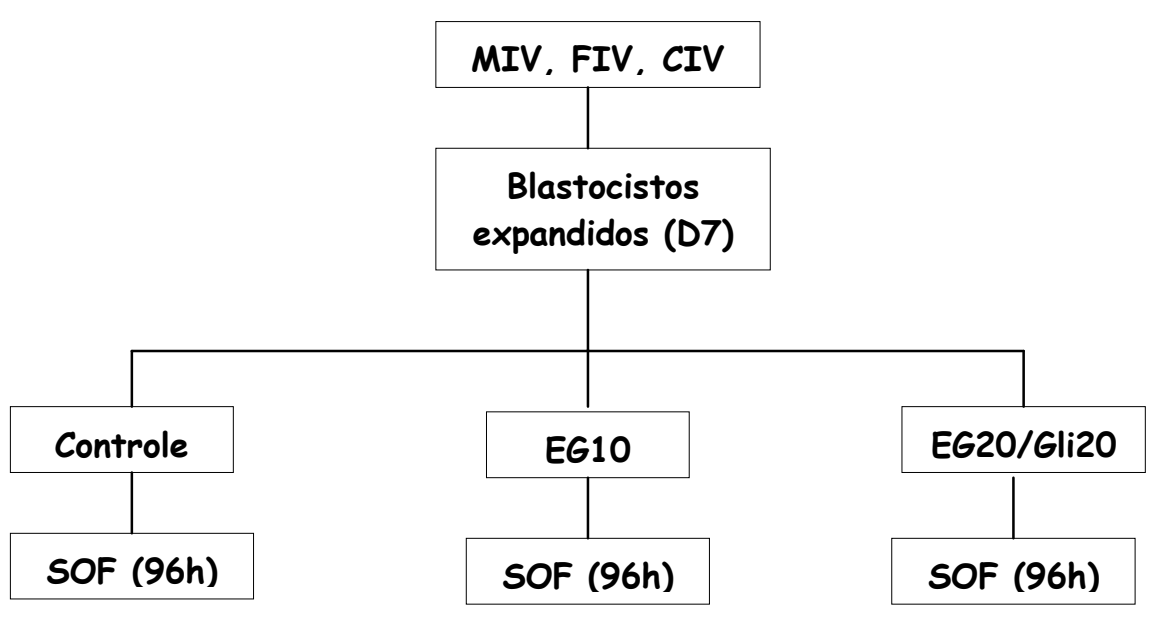

6.2 Experimento 2: Avaliação da sobrevivência dos embriões à criopreservação

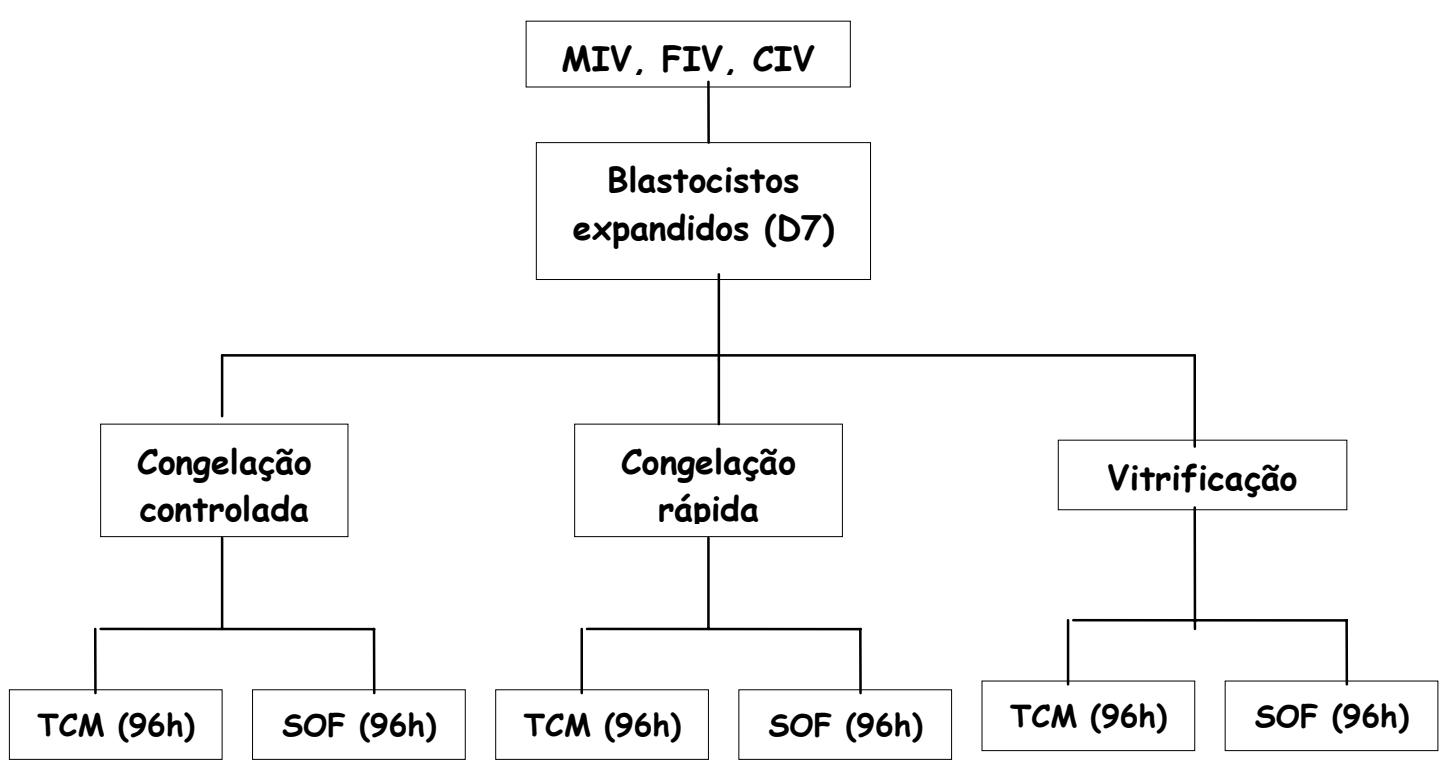


6.3 Experimento 3: Análise da expressão gênica em embriões criopreservados e frescos

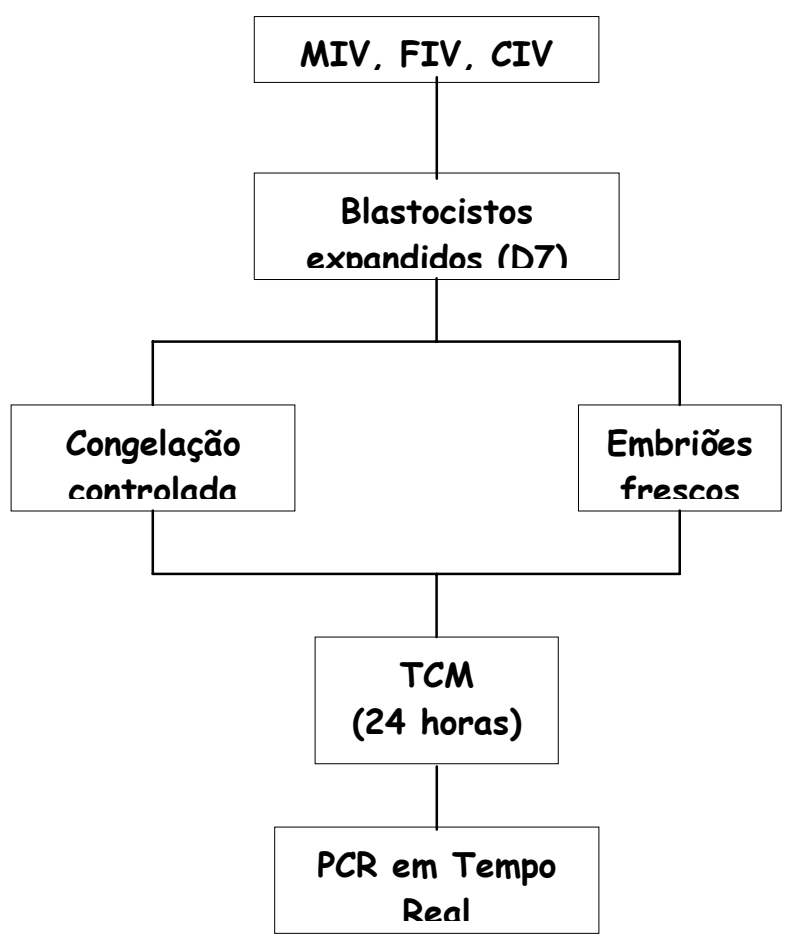




\section{Resultados}




\section{RESULTADOS}

Foram realizadas manipulações (Maturação, Fecundação e Cultivo in vitro) e observados os índices de clivagem no dia 3 (D3 - 68,71\%), blastocisto no dia 9 (D9 25,66\%) e eclosão dos blastocistos no dia 12 de cultivo (D12 - 46,09\%) de embriões não tratados.

7.1 Experimento 1: Avaliação da sobrevivência dos embriões à exposição aos crioprotetores

Foram selecionados 273 blastocistos expandidos de qualidade excelente (grau 1), sendo distribuídos 101 para o grupo EG 10, 100 para o grupo EG20/Gli20 e 72 para o grupo controle, totalizando 11 réplicas. Os índices de eclosão foram de 62,38\%, $69,00 \%$ e $59,72 \%$, respectivamente (Tabela 1 ). 
Tabela 1 - Índices de eclosão dos embriões expostos às soluções crioprotetoras EG 10 e EG20+Gly20 e controle - São Paulo - 2007.

\begin{tabular}{c|ccc} 
Réplicas & Eclosão EG10 (\%) & Eclosão 20/20 (\%) & Eclosão Controle (\%) \\
\hline 1 & $16 / 17$ & $16 / 18$ & $6 / 6$ \\
2 & $7 / 12$ & $6 / 13$ & $6 / 15$ \\
3 & $6 / 7$ & $7 / 7$ & $8 / 14$ \\
4 & $0 / 5$ & $1 / 4$ & $1 / 1$ \\
5 & $3 / 10$ & $6 / 10$ & $1 / 2$ \\
6 & $3 / 5$ & $4 / 6$ & $3 / 5$ \\
7 & $7 / 10$ & $9 / 11$ & $4 / 5$ \\
8 & $9 / 9$ & $7 / 7$ & $3 / 7$ \\
9 & $3 / 5$ & $0 / 4$ & $1 / 3$ \\
10 & $9 / 14$ & $8 / 13$ & $8 / 8$ \\
11 & $0 / 7$ & $5 / 7$ & $2 / 6$ \\
\hline Total & $63 / 101(62,38)$ & $69 / 100(69,00)$ & $43 / 72(59,72)$ \\
\hline
\end{tabular}

Os resultados da análise estatística realizada pelo Teste PROC MIXED do SAS ${ }^{\circledR}$ não mostraram diferença entre os grupos de exposição e o grupo controle. Portanto, a exposição às soluções crioprotetoras não influenciou a sobrevivência dos blastocistos (Tabela 2).

Tabela 2 - Índices de eclosão dos embriões expostos às soluções crioprotetoras EG 10, EG20/Gly20 e controle - São Paulo - 2007

\begin{tabular}{l|c|c|c}
\multicolumn{1}{c|}{ Tratamento } & $\begin{array}{c}\text { Número de } \\
\text { Blastocistos }\end{array}$ & Média \pm EPM & Valor de $\mathbf{p}$ \\
\hline EG10 & 101 & $58,94 \pm 9,43$ & 0,5685 \\
EG20/Gli20 & 100 & $65,55 \pm 9,43$ & 0,8734 \\
Controle & 72 & $60,78 \pm 9,43$ & 0,6801 \\
\hline
\end{tabular}

Letras minúsculas diferentes na mesma coluna indicam diferença estatística pelo Teste PROC MIXED $(p<0,05)$.

\subsection{Experimento 2: Avaliação da sobrevivência dos embriões à criopreservação}

Foram utilizados 600 blastocistos expandidos de qualidade excelente (grau 1), sendo 199 para a congelação controlada, 200 para a congelação rápida e 201 para 
a vitrificação. Após a descongelação, os embriões foram divididos entre os meios de cultivo TCM199 ou SOFaa, sendo cultivados 99 no TCM199 100 e no meio SOFaa no método controlado; 103 no TCM199 e 97 no meio SOFaa na congelação rápida e 101 no TCM199 e 100 no meio SOFaa na vitrificação. Foram feitas 5 replicatas para cada meio de cultivo (TCM199 ou SOFaa).

O método controlado apresentou índices de re-expansão de 58,58\%, quando os embriões foram cultivados no meio TCM199, enquanto o método rápido apresentou $1,61 \%$ e a vitrificação $13,65 \%$. Constatamos que houve diferença entre o método controlado e os demais métodos, embora entre os demais métodos não tenha sido constatada diferença. O método controlado apresentou índices de eclosão dos blastocistos de $44,65 \%$ quando os embriões foram cultivados no meio TCM199. O método rápido e a vitrificação apresentaram índices de eclosão de 0\% e 9,43\%, respectivamente. Constatamos que houve diferença entre o método controlado e os demais métodos, embora não tenha sido constatada diferença entre os demais métodos (Tabela3).

Tabela 3 - Índices de re-expansão e de eclosão dos blastocistos após a criopreservação pelos métodos controlado, rápido e vitrificação e cultivados no meio TCM199 - São Paulo - 2007

\begin{tabular}{l|c|c|c} 
Tratamento & Número de & \multicolumn{2}{c}{ Média \pm EPM } \\
& Blastocistos & Re-expansão & Eclosão \\
\hline Controlado & 99 & $58,58 \pm 6,94^{\mathrm{a}}$ & $44,65 \pm 5,94^{\mathrm{a}}$ \\
Rápido & 103 & $1,61 \pm 7,41^{\mathrm{b}}$ & $0 \pm 6,46^{\mathrm{b}}$ \\
Vitrificação & 101 & $13,65 \pm 7,76^{\mathrm{b}}$ & $9,43 \pm 6,77^{\mathrm{b}}$ \\
\hline
\end{tabular}

Letras minúsculas diferentes na mesma coluna indicam diferença estatística pelo Teste PROC MIXED $(p<0,05)$.

O método controlado apresentou índices de re-expansão de $34,66 \%$, quando os embriões foram cultivados no meio SOFaa. Os métodos rápido e vitrificação apresentaram índices de re-expansão de 4,32\% e 19,62\%, respectivamente. Constamos que houve diferença entre o método controlado e os demais métodos, embora não tenha havido diferença entre o método rápido e a vitrificação. Já para os índices de eclosão, o método controlado apresentou 11,65\%, enquanto o método rápido apresentou $0,29 \%$ e a vitrificação $8,67 \%$. Constamos que o método controlado foi diferente do método rápido, mas não foi diferente da vitrificação (Tabela 4). 
Tabela 4 - Índices de re-expansão e de eclosão de blastocistos após a criopreservação pelos métodos controlado, rápido e vitrificação e cultivados no meio SOFaa - São Paulo - 2007

\begin{tabular}{l|c|c|c} 
Tratamento & Número de & \multicolumn{2}{|c}{ Média \pm EPM } \\
& Blastocistos & Re-expansão & Eclosão \\
\hline Controlado & 100 & $34,66 \pm 5,39^{\mathrm{a}}$ & $11,65 \pm 3,37^{\mathrm{a}}$ \\
Rápido & 97 & $4,32 \pm 5,39^{\mathrm{b}}$ & $0,29 \pm 3,37^{\mathrm{b}}$ \\
Vitrificação & 100 & $19,62 \pm 6,95^{\mathrm{b}}$ & $8,67 \pm 4,47^{\mathrm{ab}}$
\end{tabular}

Letras minúsculas diferentes na mesma coluna indicam diferença estatística pelo Teste PROC MIXED $(p<0,05)$.

\subsection{Experimento 3: Análise da expressão gênica em embriões criopreservados e} frescos

A figura 1 mostra que a amplificação do primer âncora 3 com amostra de cDNA de embriões bovinos frescos, teve início a partir do $36^{\circ}$ ciclo de amplificação, indicando que havia pouco cDNA disponível para a reação.

Figura 1: Quantificação da amplificação do primer âncora 3 com amostra de cDNA de embriões bovinos frescos

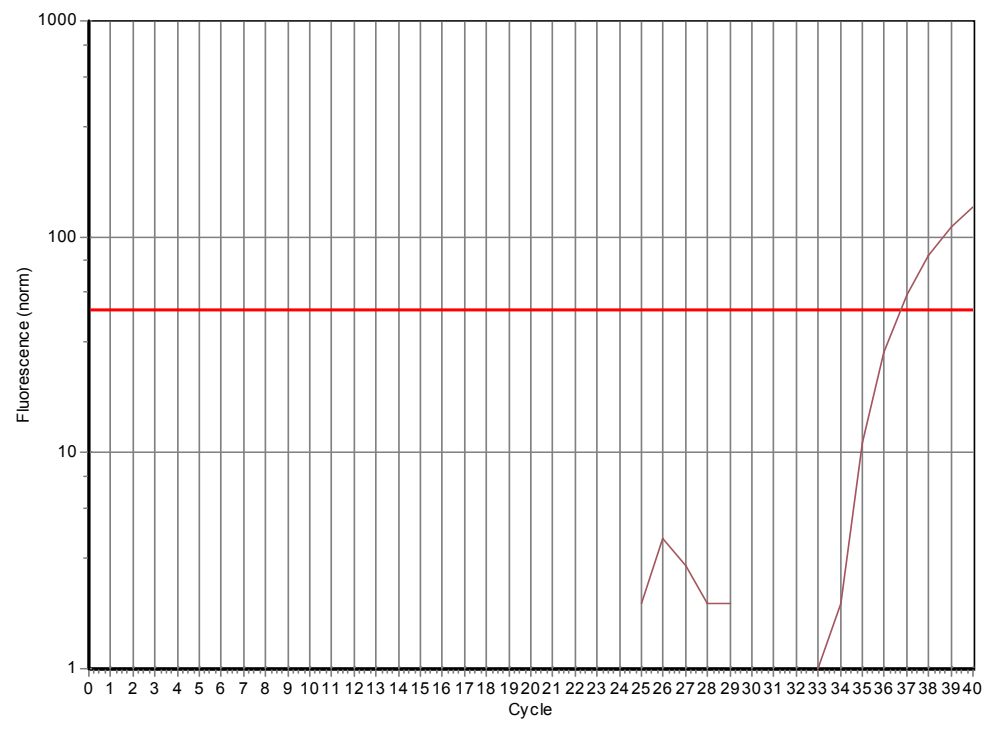


A figura 2 mostra que não houve amplificação dos produtos do primer âncora 3 com amostra de cDNA de embriões bovinos criopreservados pelo método controlado $\left(1,2^{\circ} \mathrm{C} /\right.$ minuto $)$, indicando não haver cDNA inicial suficiente para acontecer a reação.

Figura 2: Quantificação da amplificação do primer âncora 3 com amostra de cDNA de embriões bovinos criopreservados pelo método controloado $\left(1,2^{\circ} \mathrm{C} /\right.$ minuto)

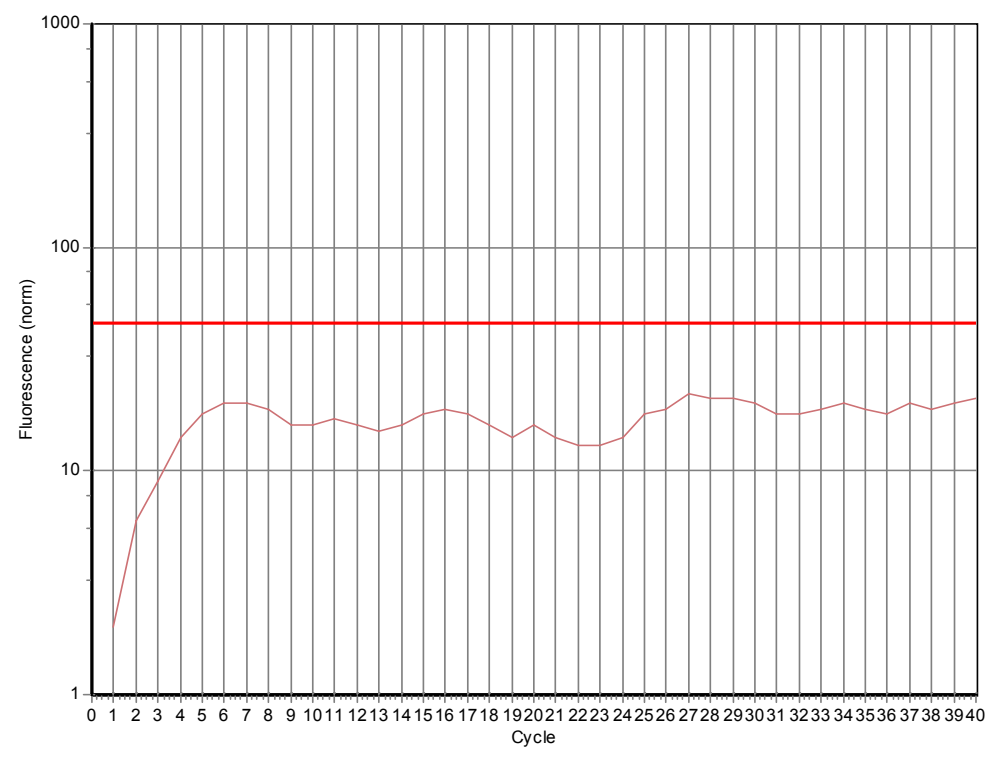

A figura 3 mostra que a amplificação do primer GAPDH com amostra de cDNA de embriões suínos (controle positivo) começou a acontecer a partir do $33^{\circ}$ ciclo de amplificação. 
Figura 3: Quantificação da amplificação do primer GAPDH com amostra de cDNA de embriões suínos (controle positivo)

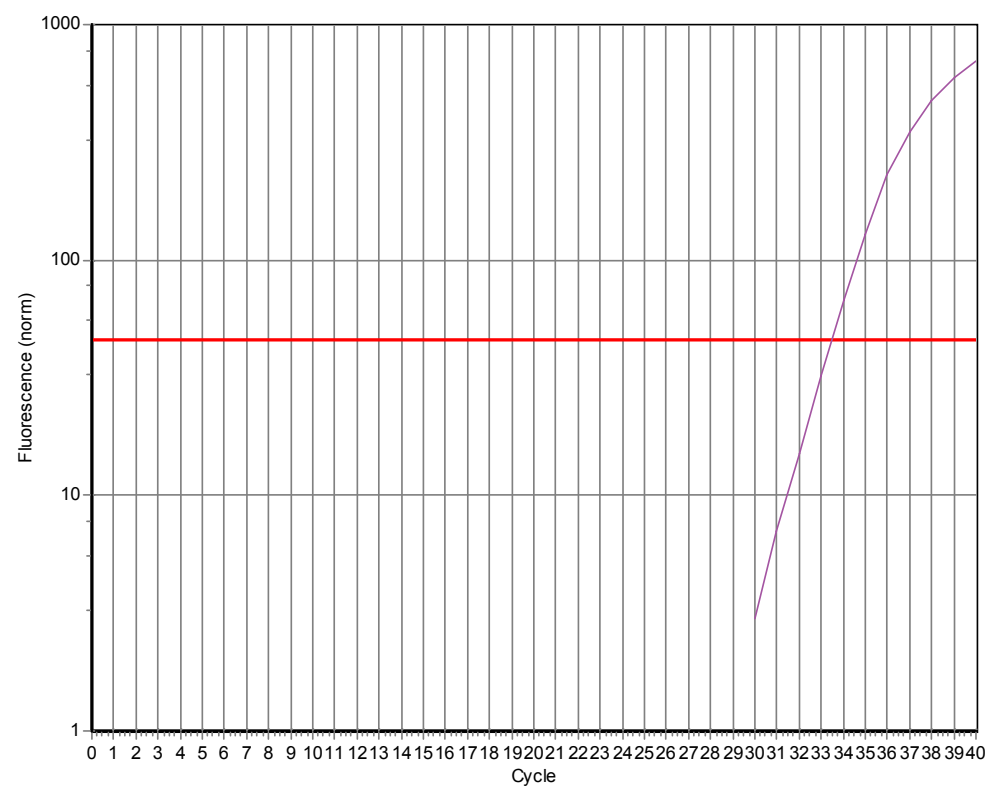

Ao comparar as curvas de amplificação dos embriões do grupo fresco com o grupo congelado (Figuras 2 e 3, respectivamente) podemos observar que o mesmo primer âncora teve amplificação no grupo fresco e não teve no grupo congelado, indicando a diferença de cDNA inicial entre os grupos e indicando, também, que as condições de reação são apropriadas para o primer.

Ao comparar os resultados do grupo de embriões suínos frescos com o grupo de embriões bovinos frescos verificamos que a amplificação do grupo fresco foi mais tardia $\left(36^{\circ}\right.$ ciclo contra $33^{\circ}$ ciclo), mostrando novamente haver pouca quantidade de cDNA inicial para a reação.

A figura 4 mostra que o pico da curva de dissociação (melting curve) aconteceu entre 86 e $87^{\circ} \mathrm{C}$, portanto, sendo indicativo de que os produtos da reação não são dímeros de primers. 
Figura 4: Curva de dissociação para primer âncora 3 com embriões bovinos frescos

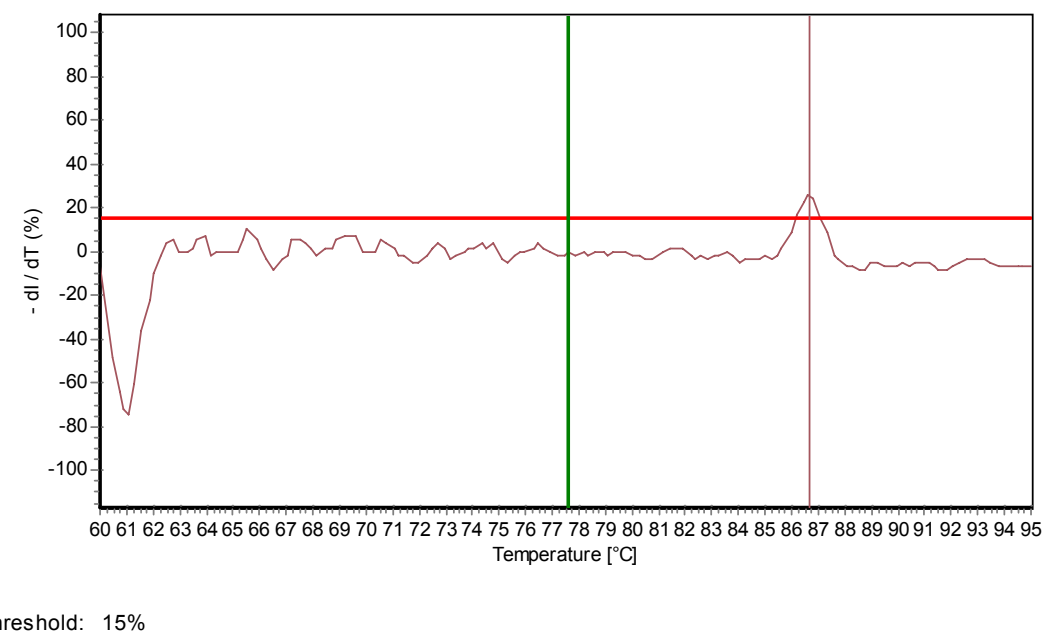

A figura 5 mostra que não houve um pico de dissociação nesta reação, caracterizando a ausência de produtos na reação.

Figura 5: Curva de dissociação para primer âncora 3 com embriões bovinos criopreservados pelo método controlado $\left(1,2^{\circ} \mathrm{C} /\right.$ minuto $)$

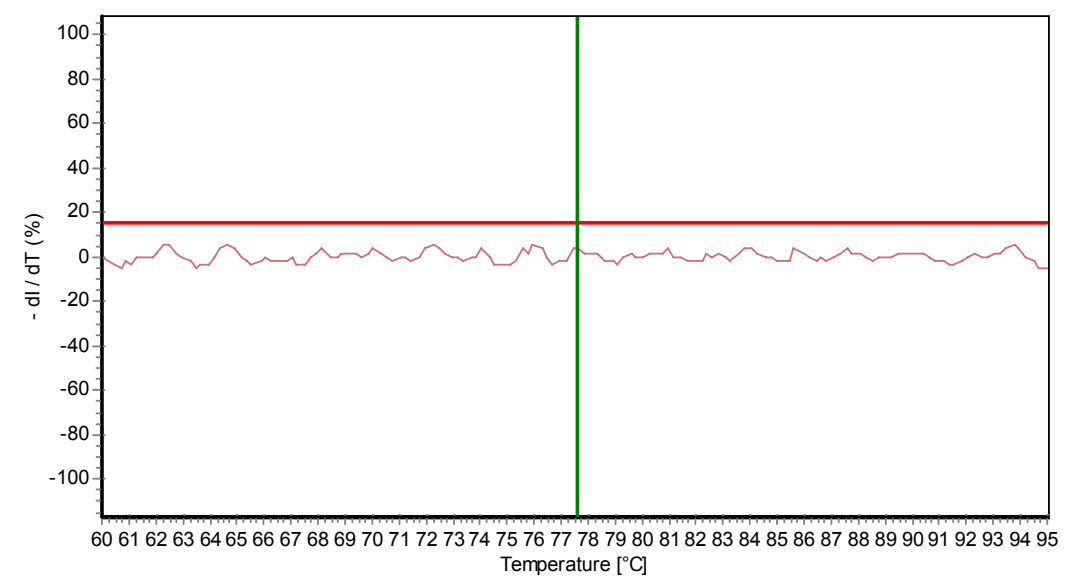

Threshold: $15 \%$

A figura 6 mostra o pico de dissociação do grupo de embriões suínos (controle positivo) entre 87 e $88^{\circ} \mathrm{C}$, caracterizando a presença de produtos de amplificação que não são dímeros de primer. 
Figura 6: Curva de dissociação para primer GAPDH com amostra de cDNA de embriões suínos (controle positivo)

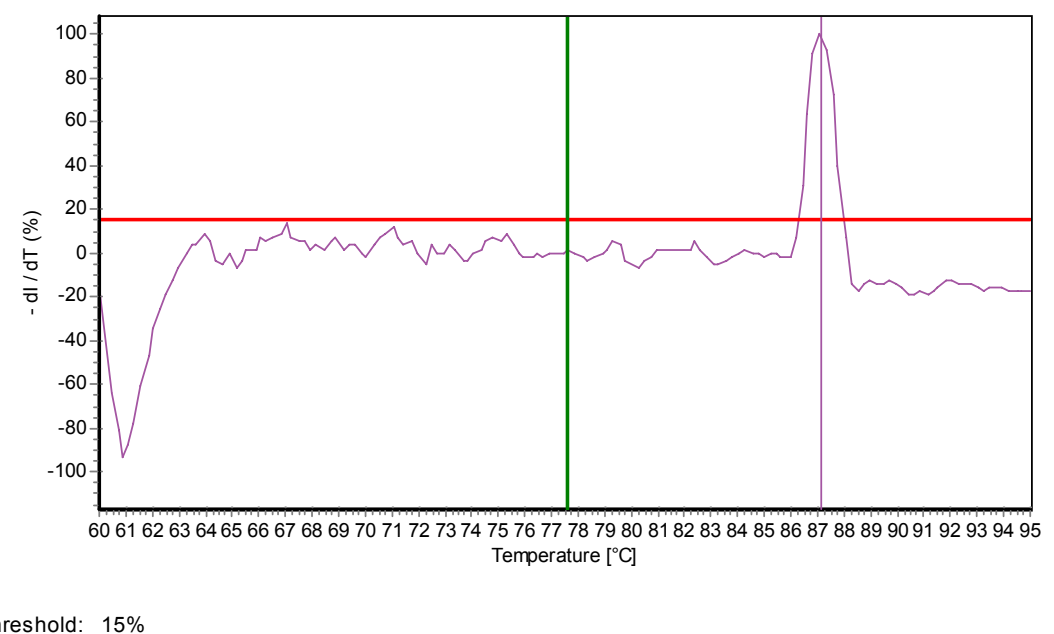

A comparação entre os grupos frescos e suínos (figuras 4 e 6 , respectivamente) permite novamente verificar a existência de menor quantidade de produtos da reação no grupo de embriões frescos. 
Discussão 


\section{DISCUSSÃO}

A criopreservação de embriões é um obstáculo para a aplicação comercial extensiva da produção in vitro de embriões bovinos. Muitos protocolos de produção in vitro e de criopreservação vêm sendo utilizados. Seguindo esta linha, o presente trabalho avaliou protocolos de criopreservação de embriões e de viabilidade embrionária após a descongelação para incrementar a produção in vitro de embriões bovinos para uso comercial.

Foram realizados experimentos para avaliar a toxicidade das soluções crioprotetoras, as quais se mostraram satisfatórias. Os embriões apresentaram desenvolvimento normal após a exposição, não havendo diferença entre os índices de eclosão do grupo controle e dos grupos experimentais, indicando que as soluções crioprotetoras não foram deletérias ao desenvolvimento embrionário.

Realizaram-se experimentos de congelação de embriões pelos métodos controlado, rápido e vitrificação. Os índices de eclosão foram baixos após a criopreservação pelos métodos rápido e vitrificação, os quais foram deletérios ao desenvolvimento embrionário, no entanto, a congelação controlada mostrou índices mais altos e adequados.

Em estudo recente, Mucci et al. (2005) observaram que imediatamente após a descongelação, os embriões sofriam contração, mostrando um esboço de citoplasma e aparência morfológica normal. Porém, após 30 minutos de cultivo, os embriões apresentavam-se regredidos, com aparência escura e debris celulares visíveis no espaço perivitelínico. No presente trabalho, também se verificou este aspecto morfológico aparentemente normal nos embriões dos grupos rápido e vitrificação, sendo os índices de re-expansão e de eclosão mais baixos. Já os embriões do grupo controlado apresentavam-se com grande redução de citoplasma e aumento de espaço perivitelínico, porém, após 24 horas de cultivo, apresentaram os melhores índices de sobrevivência. 
Dentre os protocolos utilizados para a congelação controlada, os pontos comuns são o equilíbrio dos embriões na solução crioprotetora (contendo entre 10 e $11 \%$ de crioprotetor permeável) por 5 a 10 minutos a temperatura ambiente $\left(20\right.$ a $\left.25^{\circ} \mathrm{C}\right)$, a indução da cristalização (seeding) quando as palhetas atingem entre $-5^{\circ} \mathrm{C}$ a $-9^{\circ} \mathrm{C}$, o resfriamento a velocidade entre $0,3^{\circ} \mathrm{C}$ a $0,6^{\circ} \mathrm{C}$ por minuto até atingir temperatura entre $33^{\circ} \mathrm{C}$ a $-40^{\circ} \mathrm{C}$, sendo as palhetas imersas em nitrogênio líquido (MOORE; BONILLA, 2006).

Entretanto, os protocolos de congelação controlada são extremamente demorados, sendo necessário, conforme o protocolo usado, mais de uma hora para o processo todo. No intuito de diminuir esse tempo necessário, o presente trabalho utilizou velocidade de resfriamento mais rápida $\left(1,2^{\circ} \mathrm{C} /\right.$ minuto), seguindo trabalhos anteriores realizados pelo nosso grupo de pesquisa. Assumpção (2001) comparou a sobrevivência de embriões bovinos produzidos in vitro após a criopreservação pelo método controlado utilizando as velocidades de resfriamento de $0,5^{\circ} \mathrm{C}$ por minuto e $1,2^{\circ} \mathrm{C}$ por minuto e não encontrou diferença.

A congelação controlada (resfriamento de $1,2^{\circ} \mathrm{C} /$ minuto) apresentou índices de re-expansão e eclosão aquém do esperado, em comparação aos trabalhos de Assumpção (2001) e Nicacio (2003). A diferença de metodologia entre os três trabalhos foi o meio de cultivo após a descongelação, sendo no presente, inicialmente, o meio SOFaa e nos outros dois trabalhos o meio TCM199 acrescido de SFB, piruvato e gentamicina, ambos em co-cultivo com células da granulosa. Dessa forma, realizaramse experimentos para verificar a influência dos meios de cultivo após a descongelação na viabilidade embrionária, quando foi observado que os índices de re-expansão e de eclosão no meio TCM199 foram maiores do que no SOFaa.

Verificou-se, neste trabalho, que a congelação controlada obteve melhor índice de sobrevivência in vitro do que a vitrificação para embriões bovinos produzidos em sistema de co-cultivo com células da granulosa em meio SOFaa. O mesmo foi observado por Campos-Chillon et al. (2006) que, ao compararem protocolos de criopreservação com glicerol tanto para a congelação controlada quanto para a vitrificação, verificaram índices de prenhez praticamente idênticos para ambos os 
métodos (controlado $45,1 \%$ e vitrificação $44,5 \%$ ), sendo a vitrificação descartada da rotina de criopreservação.

Donnay et al. (1998) vitrificaram blastocistos em solução de $25 \%$ de etileno glicol e $25 \%$ de glicerol, obtendo $53 \%$ de eclosão após 72 horas de co-cultivo no meio TCM199 com células BRL (Buffalo Rat Liver). No presente estudo, este protocolo de criopreservação apresentou entre 6 e 7\% de eclosão, conforme o meio de cultivo. Embora a solução crioprotetora final tenha sido a mesma, o procedimento de equilíbrio dos embriões na solução foi diferente, sendo, no presente trabalho, feito em duas etapas de exposição em concentrações crescentes e, no estudo de Donnay et al. (1998), feito em três etapas em concentrações crescentes. Acredita-se que a exposição em três etapas tenha sido menos deletéria aos embriões, o que explica a melhor sobrevivência embrionária. Além disso, o diferente sistema de produção de embriões talvez tenha sido outro motivo para a diferença de respostas.

O mesmo resultado foi observado em estudo realizado por Kaidi et al. (1998), quando embriões bovinos produzidos in vitro foram vitrificados em solução de $25 \%$ de etileno glicol e $25 \%$ de glicerol, com a exposição em 3 etapas de concentrações crescentes, obtendo índices de eclosão entre 32 e $81 \%$, conforme as condições de cultivo após a descongelação.

Em estudo visando comparar os efeitos da congelação controlada $\left(0,3^{\circ} \mathrm{C} /\right.$ minuto) e da vitrificação ( $25 \%$ de etileno glicol e $25 \%$ de glicerol, em 3 etapas de concentrações crescentes) sobre o metabolismo e morfologia de embriões bovinos produzidos in vitro, Kaidi et al. (2001) não obtiveram diferença entre os índices de reexpansão e eclosão entre os dois protocolos testados e concluíram que ambos os processos de criopreservação causaram danos ao metabolismo e às células embrionárias, mesmo que por mecanismos diferentes, indicando porque ocorrem as perdas embrionárias após a transferência.

Os resultados do presente trabalho não corroboram com a literatura, pois houve diferença entre os índices de re-expansão e de eclosão, conforme o protocolo, sendo que a congelação controlada (congelação lenta) apresentou resultado mais satisfatório em relação a congelação rápida e a vitrificação. 
Já foi mostrado, em vários estudos, que o uso de soro fetal nos meios de cultivo induz à produção de embriões com maior quantidade de lipídeos no citoplasma. Assim, como já foi demonstrado em vários estudos, embriões com maior quantidade de lipídeos são mais sensíveis à criopreservação (RIZOS et al., 2002; LONERGAN et al., 2003; RIZOS et al., 2003; SEIDEL et al., 2006). Tendo em vista que os embriões deste trabalho foram produzidos em meio SOFaa acrescido de Soro fetal Bovino (SFB), acreditamos que estes embriões apresentaram quantidade de lipídeos elevada, comprometendo sua criotolerância, justificando os índices menores de sobrevivência após a congelação rápida e a vitrificação em comparação com dados da literatura.

Para facilitar o procedimento de transferência dos embriões após a criopreservação foi desenvolvido por Leibo e Loskutoff (1993) uma maneira de remover o crioprotetor dos embriões ainda na palheta (método "one step"). Para tal, nas extremidades da palheta deve ser colocada uma solução contendo entre 0,3 e 1,0M de sacarose (VAN WAGTENDONK -DE LEEUW et al., 1995). A sacarose vem sendo utilizada na remoção de crioprotetores permeáveis tanto em protocolos de congelação lenta (controlada) quanto em protocolos de vitrificação (AGCA et al., 1998).

O uso da sacarose visa permitir que o crioprotetor deixe o interior das células embrionárias passivamente e por ser um agente impermeável às células serve para manter o equilíbrio osmótico durante a descongelação, evitando a entrada de grande quantidade de água nas células e, conseqüentemente, o choque osmótico ao embrião (FAHNING; GARCIA, 1992; KASAI, 2002; MOORE; BONILA, 2006).

Durante a remoção dos crioprotetores permeáveis por difusão, usando a sacarose na solução, os embriões permanecem contraídos. Esta condição de contração das células pode ser prejudicial aos embriões (KASAI, 2002). Quando os embriões se contraem muito em resposta a hipertonicidade do meio externo, alterando seu volume, a membrana plasmática das células pode ser afetada, perdendo sua integridade e o citoesqueleto pode perder sua organização. Portanto, existe um limite de tolerância do embrião ao estresse osmótico, que deve ser determinado. Enquanto esse limite não é estabelecido e nem outras possíveis conseqüências são determinadas, os protocolos devem ser observados com cautela (AGCA et al., 1998). 
No presente trabalho utilizamos a concentração de $0,3 \mathrm{M}$ de sacarose, embora não seja possível determinar o verdadeiro efeito da sacarose, uma vez que apenas o grupo controlado apresentou resultados satisfatórios. Consideramos a possibilidade de que esta concentração de sacarose não foi suficiente para a remoção dos crioprotetores e reidratação adequada dos embriões dos grupos de congelação rápida e vitrificação, sendo possível a ocorrência de choque osmótico no momento da descongelação.

Para evitar esse estresse aos embriões, os crioprotetores devem ser removidos em etapas, ou seja, os embriões devem passar por soluções menos hipertônicas e depois por soluções isotônicas (KASAI, 2002). Mais uma vez, o procedimento foi executado, porém não é possível concluir sobre sua influência, já que apenas o grupo controlado obteve resultados satisfatórios, sendo possível que os embriões tenham sofrido esse estresse osmótico.

Uma modificação nos procedimentos de criopreservação é manter as palhetas com os embriões em vapor de nitrogênio líquido $\left(-170^{\circ} \mathrm{C}\right)$, visando tanto diminuir as rupturas de zona pelúcida quanto das palhetas (VAN WAGTENDONK -DE LEEUW et al., 1995).

A fratura das células embrionárias ou da zona pelúcida acontece devido às mudanças não uniformes de volume das soluções durante sua solidificação. Para minimizar estas ocorrências, a temperatura crítica (ao redor de $-130^{\circ} \mathrm{C}$ ) em que ocorre a mudança de fase da solução deve ser passada rapidamente, tanto na congelação quanto na descongelação. São, ainda, relatadas fraturas nas palhetas onde os embriões são acondicionados. Para evitar essas fraturas de palhetas recomenda-se o uso de estruturas mais flexíveis ou a congelação em vapor de nitrogênio (KASAl, 2002).

Um dos protocolos (grupo de congelação rápida) foi feito em vapor de nitrogênio e não foi verificada pela análise morfológica dos embriões nenhuma fratura de zona pelúcida. Entretanto, devemos salientar que em nenhum dos grupos experimentais este dano foi verificado quando morfologicamente avaliados os embriões após a criopreservação. Logicamente, uma análise ultra-estrutural com auxílio de microscopia eletrônica, talvez permitisse a observação mais acurada dos danos ocorridos na zona pelúcida dos embriões deste trabalho. 
Outra maneira de minimizar as fraturas de zona pelúcida é pela descongelação em ar e não diretamente em banho-maria a 20 ou $36^{\circ} \mathrm{C}$ (FAHNING; GARCIA, 1992). O mesmo procedimento de descongelação foi feito neste trabalho e não verificamos a ocorrência de fraturas na zona pelúcida. Mais uma vez, salientamos que a análise feita foi apenas morfológica e que uma análise ultra-estrutural seria mais acurada e eficiente para estas conclusões.

Como as condições experimentais e os protocolos de criopreservação de embriões variam muito entre os trabalhos, é difícil comparar os índices de prenhez (van WAGTENDONK -DE LEEUW et al., 1995).

Muitos estudos avaliaram a influência das condições de cultivo na produção de embriões, visando melhorar sua qualidade (KHURANA; NIEMANN, 2000b; NIEMANN; WRENZYCKI, 2000; FAIR et al., 2001; DOBRINSKY, 2002; LEONI; et al., 2002; MOHAN et al., 2002; TESFAYE et al., 2003; PEREIRA; DODE; RUMPF, 2005; LONERGAN et al., 2006).

Entretanto, poucos estudos avaliaram a influência das condições de cultivo após a descongelação. Massip et al. (1993) testaram a influência do co-cultivo no meio para cultivar embriões após a criopreservação. Os embriões foram criopreservados pelo método controlado (congelação lenta) e cultivados na presença ou ausência de células epiteliais bovinas no co-cultivo, demonstrando que 0 co-cultivo influenciou positivamente os índices de re-expansão e eclosão (MASSIP et al., 1993).

Com resultados demonstrando que o mesmo protocolo de vitrificação (25\% de etileno glicol e $25 \%$ de glicerol) apresentou diferentes índices de sobrevivência e eclosão conforme o meio de cultivo, Kaidi et al. (1998) afirmaram que houve influência do cultivo após a descongelação.

No presente trabalho, os índices de eclosão também variaram em função do meio de cultivo para o protocolo de congelação controlada (congelação lenta). Acreditase que os protocolos de congelação rápida e vitrificação não tenham apresentado influência semelhante devido aos danos que os processos de criopreservação tenham causado aos embriões, sendo estes descongelados sem condições de sobrevivência, independente do meio de cultivo. 
Muitos trabalhos avaliam a viabilidade in vitro dos embriões e salientam a necessidade de estabelecer maneiras mais confiáveis para avaliar os embriões, uma vez que o estabelecimento de prenhez e nascimento de animais saudáveis é o método mais confiável, assim como mais demorado e honeroso (KAIDI et al., 1998; PUGH; TERVIT; NIEMANN, 2000; RIZOS et al., 2001; MARTINEZ et al., 2002; HOSHI, 2003; RUSSELL et al., 2006; LIM et al., 2007).

Sabe-se da dificuldade de transferir embriões produzidos in vitro a partir de oócitos oriundos de ovários de matadouro para avaliar a viabilidade in vivo. Considerase a viabilidade in vitro um método importante para analisar os embriões. Em virtude dos resultados do presente trabalho, a influência do meio de cultivo após a descongelação deve ser considerada, pois um mesmo protocolo de criopreservação, realizado sob as mesmas condições experimentais, apresentou índices de sobrevivência diferentes conforme o meio utilizado na análise de sua viabilidade. Para tornar esta análise mais precisa, acredita-se que mais trabalhos possam ser executados. A criopreservação de embriões produzidos in vitro é o objetivo final, porém ainda existem muitos fatores a serem estudados até que seja encontrado um protocolo adequado.

Uma das maneiras de analisar a influência do meio de cultivo é avaliar a expressão gênica dos embriões nos diferentes meios, não apenas antes, mas também após a criopreservação. Uma das ferramentas moleculares de eleição para a realização desta análise é a técnica de Differential Display (DD-RT-PCR).

A técnica denominada DD-RT-PCR foi explicada por Sirard et al. (2007) como um mecanismo comum de análise de RNAm baseado na amplificação com um sistema de amplificação linear que usa um primer T-7, sendo transcrito um antisenso do RNAm inicial que é amplificado e, se necessário, uma segunda amplificação pode ser feita ao ser repetido o procedimento. Uma das principais vantagens é a necessidade de pequeno número de embriões para a realização da análise, pois os produtos podem ser clonados e seqüenciados (ZIMMERMANN; SCHULTZ, 1994), sendo possível realizar todo o processo com entre 5 e 10ng de RNA e as amostras podem ser analisadas em gel (PONSUKSILI et al., 2002). 
Para determinar as bases moleculares do desenvolvimento de embriões préimplantacionais, a expressão diferencial de genes de interesse deve ser identificada e analisada detalhadamente. Entretanto, a quantidade de RNAm em embriões é limitada. Reações de Transcrição Reversa associada com reações de PCR (RT-PCR) permitem detectar raras mensagens em amostras biológicas pequenas e tem sido o método de escolha para estudar individualmente genes em análises individuais de embriões (WRENZYCKI; HERRMANN; NIEMANN, 2007).

Tesfaye et al. (2005) compararam o padrão de embriões em diferentes estágios de desenvolvimento e identificaram possíveis genes alvo. Dessa forma, confirmaram a possibilidade de utilizar a técnica de DD-RT-PCR para identificar genes diferencialmente expressos. E ainda, utilizaram o monitoramento da fluorescência, executando a reação de PCR em Tempo Real para validar os resultados da DD-RTPCR e quantificar com acurácia os transcritos.

A técnica de DD-RT-PCR tem limitações como a alta quantidade de falsos positivos e a necessidade de isolar os fragmentos do gel e repetir a sua amplificação e clonagem (PONSUKSILI et al., 2002), sendo recomendado a realização de análise com PCR em Tempo Real para validação dos resultados (TESFAYE et al., 2005). Além disso, a análise por PCR em Tempo Real permite quantificar a quantidade inicial de material e eliminar a necessidade de análise em gel dos produtos (LECHNIAK, 2002), sendo um método preciso e eficiente para avaliar os níveis de transcritos de múltiplos genes com pequenas amostras de embriões (ROBERT et al., 2002).

Em bovinos, a transcrição tem níveis muito baixos antes do estágio de oito células, quando acontece a ativação do genoma embrionário. Porém, a queda na quantidade de RNAm ao longo do desenvolvimento embrionário não é necessariamente devido a transcrição que esteja ocorrendo, mas sim devido a degradação deste RNAm de origem materno. Portanto, a interpretação dos níveis de RNAm deve ser considerada de maneira diferente entre os embriões antes e após a ativação do genoma embrionário (SIRARD et al., 2005).

Além disso, os níveis de RNAm provavelmente não refletem os níveis protéicos apresentados pelo embrião, embora muitos dos sistemas regulatórios que atuam em embriões possam ser analisados já que a transcrição é a primeira resposta 
celular à diferenciação ou aos estímulos de desenvolvimento. Dessa forma, a análise da expressão permite examinar a resposta embrionária às mudanças ambientais ou ao desenvolvimento (SIRARD et al., 2005).

Embora a literatura relate a necessidade de pouco material para a execução de técnicas como a análise de expressão gênica pela DD-RT-PCR e para a técnica de PCR em Tempo Real (TESFAYE et al., 2005), neste trabalho encontramos dificuldade em executar a análise com a mesma quantidade de embriões referidos na literatura. $O$ uso da técnica de PCR em Tempo Real, monitorada por fluorescência, tem emergido como uma importante ferramenta para validar os resultados da análise por DD-RT-PCR, análise serial de expressão gênica (SAGE) a experimentos de cDNA, requerendo menos RNAm (TESFAYE et al., 2005). Por isso a técnica de PCR em Tempo Real foi escolhida para analisar os produtos da reação de Transcrição Reversa (RT-PCR) neste trabalho.

Pikó e Clegg (1982), ao estudarem as mudanças quantitativas de RNA total presente em embriões murinos, relataram que a quantidade de RNA presente entre os estágios de 2 células, 8-16 células e blastocisto inicial, aumentou significativamente $(p<0,001)$. A partir do estágio de 2 células, o RNA presente nestes embriões aumentou rapidamente, sendo que os embriões de 8-16 células apresentaram cerca de duas vezes mais RNA e os blastocistos iniciais apresentaram seis vezes mais RNA. E, ainda, neste trabalho, Pikó e Clegg relataram que blastocistos iniciais murinos (com 32 células) apresentam, em média, 1,47 $\pm 0,08$ ng de RNA.

Zimmermann e Schultz (1994), ao executarem a técnica de DD-RT-PCR em embriões murinos, utilizaram 50 embriões em estágio de 2 células, 25 embriões em estágio de 8 células e 10 embriões em estágio de blastocisto, sendo estes valores equivalentes a 10pg de RNA.

Corcoran et al. (2007), ao analisarem a expressão temporal de transcritos relacionados com a qualidade embrionária de embriões bovinos cultivados entre os estágios de 2 células até blastocistos, utilizaram 5 pools de 10 embriões por estágio para realizar a análise quantitativa por PCR em Tempo Real.

Goossens et al. (2005), ao realizarem um estudo envolvendo análise quantitativa em PCR em Tempo Real em embriões bovinos pré-implantacionais, 
utilizaram pools de 20 embriões para a extração de RNA. Como a quantidade de RNA era muito pequena, não foi possível quantificar as amostras em espectrofotômetro.

No presente trabalho, foram utilizados 2 pools de 10 blastocistos expandidos, tanto para os embriões do grupo criopreservado quanto para os grupos de embriões frescos. Porém, a análise feita com PCR em Tempo Real permitiu observar que as amplificações começaram a acontecer tardiamente em comparação com o controle positivo, indicando que a quantidade de RNAm e cDNA não foram suficientes para visualização de transcritos em gel de agarose e nem mesmo em gel de poliacrilamida. Acreditamos que, ao aumentar a quantidade de embriões, haverá aumento do RNAm disponível, sendo possível a transcrição de cDNA e sua amplificação e, assim, seja possível realizar a análise da expressão gênica destes grupos experimentais.

A análise com PCR em Tempo Real também permitiu verificar que houve diferença de resposta conforme o primer âncora, ou seja, um primer âncora apenas apresentou amplificação, indicando uma possível deficiência ou inatividade de alguns primers ou da reação.

Da mesma maneira, como um primer âncora apresentou amplificação apenas no grupo de embriões frescos e não apresentou amplificação no grupo de embriões criopreservados, acreditamos ser devido a pequena quantidade de RNAm e cDNA disponíveis para as reações. O que está de acordo com a literatura que relata a degradação de RNAm durante o processo de criopreservação de embriões humanos de 2 células (GARDNER; LANE, 2005).

Condições subótimas de cultivo durante o período pré-implantacional podem alterar a degradação do RNAm tanto de origem materna, quando acontece durante a maturação oocitária, quanto de origem embrionária, quando acontece durante o período de ativação do genoma embrionário (BADR et al., 2007).

Novas técnicas de mensurar níveis de RNA de embriões em estágio préimplantacional pela reação de transcrição reversa (RT-PCR) vem sendo desenvolvida e utilizada por ser menos laboriosa do que técnicas como o Northern blot. Entretanto, em virtude de sua eficiência e cinética, o produto final após a amplificação pode não ser acurado e refletir a concentração inicial de RNA da amostra. A técnica de PCR em Tempo Real em que os dados são geralmente normalizados é bem menos variável do 
que a técnica convencional de RT-PCR, não tendo os resultados influenciados por escassez de algum componente da reação no nível de plateau, fornecendo a quantificação mais precisa e sensível da quantidade de RNA presente na amostra. $E$ ainda é uma técnica bastante interessante quando há pouca disponibilidade de células para análise (GOOSSENS et al., 2005). 
Conclusões 


\section{CONCLUSÕES}

O método de congelação controlada, com velocidade de resfriamento de $1,2^{\circ} \mathrm{C}$ por minuto, apresentou índice de viabilidade in vitro adequado. Enquanto os métodos de congelação rápida e de vitrificação apresentaram menores índices de viabilidade embrionária.

O cultivo após a descongelação exerce influência sobre a viabilidade embrionária, sendo o meio TCM199 adequado para avaliar a criopreservação de embriões bovinos produzidos in vitro.

A análise da expressão gênica não foi possível com esta quantidade de embriões (20 blastocistos expandidos), tanto para os embriões criopreservados quanto para os embriões frescos. 
Referências 


\section{REFERÊNCIAS}

AGCA, Y.; LIU, J.; PETER, A. T.; CRITSER, E. S.; CRITSER, J. K. Effect of developmental stage on bovine oocyte plasma membrane water and cryoprotectant permeability characteristics. Molecular Reproduction and Development, v. 49, n. , p. 408-415, 1998.

ASSUMPÇÃO, M. E. O. A. Avaliação da sobrevivência in vitro e in vivo de embriões bovinos produzidos in vitro e congelados pelos métodos controlado, rápido e vitrificação. 200153 f. Tese (Doutorado em Medicina Veterinária) Faculdade Medicina Veterinária e Zootecnia, Universidade de São Paulo, São Paulo, 2001.

BADR, H.; BONGIONI, G.; ABDOON, A. S. S.; KANDIL, O.; PUGLISI, R. Gene expression in the in vitro-produced preimplantation bovine embryos. Zygote, v. 15, n. 4, p. 355-367, 2007.

BETTS, D.; KING, W. A Genetic regulation of embryo death and senesce.

Theriogenology, v. 55, n. 1, p. 171-191, 2001.

CAMPOS-CHILLON, L. F.; WALKER, D. J.; DE LA TORRE-SANCHEZ, J. F.; SEIDEL JR., G. E. In vitro assessment of a direct transfer vitrification procedure for bovine embryos. Theriogenology, v. 65, n. 6, p. 1200-1214, 2006.

CARNEIRO, C. S.; CAL-VIDAL, J. Estruturas de cristais de gelo em soluções aquosas contendo solutos diversos. Pesquisa Agropecuária Brasileira, v. 35, n. 2, p. 423-432, 2000.

CHANDOLIA, R. K.; PELTIER, M. R.; TIAN, W., HANSEN, P. J. Biology of Reproduction, v. 61, n. 6, p. 1644-1648, 1999.

DARVELID, U.; GUSTAFSSON, H.; SHAMSUDDIN, M.; LARSSON, B.; RODRIGUEZ MARTINEZ, $H$. Survival rate and ultra structure of vitrified bovine in vitro and in vivo development embryos. Acta Veterinaria Scandinavica, v. 35, n. 4, p. 417-426, 1994.

DOBRINSKY, J. R. Advancements in cryopreservation of domestic animal embryos.

Theriogenology, v. 57, n. 1, p. 285-302, 2002. 
DOBRINSKY, J. R. Cellular approach to cryopreservation of embryos. Theriogenology, v. 45, n. 1, p. 17-26, 1996.

DONNAY, I.; AUQUIER; P.; KAIDI, S.; CAROLAN, C.; LONERGAN, P.; MERMILLOD, P.; MASSIP, A. Vitrification of in vitro produced blastocysts: methodological studies and developmental capacity. Animal Reproduction Science, v. 52, n. 2, p. 93-104, 1998.

ENRIGHT, B. P.; LONERGAN, P.; DINNEYES, A.; FAIR, T.; WARD, F. A.; YAHG, X.; BOLAND, M. P. Culture of in vitro produced bovine zygotes in vitro vs in vivo:

implications for early embryo development and quality. Theriogenology, v. 54, n. 5, p. 659-673, 2000.

FAHNING, M. L.; GARCIA, M. A. Status of cryopreservation of embryos from domestic animals. Cryobiology, v. 29, n. , p. 1-18, 1992.

FAIR, T.; LONERGAN, P.; DINNYES, A.; COTTELL, D. C.; HYTTEL, P.; WARD, F. A.; BOLAND, M. P. Ultra structure of bovine blastocysts following cryopreservation; effect of method of blastocyst production. Molecular Reproduction and Development, v. 58, n. 2, p. 186-195, 2001.

FONTANIER-FAZZAQ, N.; McEVOY, T. G.; ROBINSON, J. J.; REES, W. D. DNA damaging agents increase gadd153 (CHOP-10) messenger RNA levels in bovine preimplantation embryos cultured in vitro. Biology of Reproduction, v. 64, n. 5, p. 1396-1391, 2001.

GARDNER, D. K.; LANE, M. Ex vivo early embryo development and effects on gene expression and imprinting. Reproduction, Fertility and Development, v. 17, n. 3, p.361-370, 2005.

GEORGE, F.; VRANCKEN, M.; VERHAEGHE, B.; VERHOEYE, F.; SCHNEIDER, Y. J.; MASSIP, A.; DONNAY, I. Freezing of in vitro produced bovine embryos in animal protein-free medium containing vegetal peptones. Theriogenology, v. 66, n. , p. 13811390, 2006.

GOOSSENS, K.; VAN POUCKE, M.; VAN SOOM, A.; VAN DESOMPELE, J.; VAN ZEVEREN, A.; PEELMAN, L. J. Selection of reference genes for quantitative real-time PCR in bovine preimplantation embryos. BMC Developmental Biology, v. 5, n. 27, p. XX, 2005. 
HANSEN, P. J. Realizing the promise of IVF in cattle-an overview. Theriogenology, v. 65, n. , p. $119-125,2006$.

HASLER, J. F. Factors affecting frozen and fresh embryo transfer pregnancy rates in cattle. Theriogenology, v. 56, n. 9, p. 1401-1415, 2001.

$\mathrm{HOSHI}, \mathrm{H}$. In vitro production of bovine embryos and their application for embryo transfer. Theriogenology, v. 59, n. 2, p. 675-685, 2003.

HYTTEL, P.; FAIR, T.; CALLESEN, H.; GREVE, T. Oocyte growth, capacitation and final maturation in cattle. Theriogenology, v. 47, n. 1, p. 23-32, 1997.

HWANG, K.; PARK, S.; PARK, S.; LIM, J. H.; CUI, X.; KIM, N. Specific maternal transcripts in bovine oocytes and cleavaged embryos: identification with novel DDRTPCR methods. Molecular Reproduction and Development, v. 71, n. 3, p. 275-283, 2005.

KAIDI, S.; BERNARD, S.; LAMBERT, P.; MASSIP, A.; DESSY, F.; DONNAY, I. Effect of conventional controlled-rate freezing and vitrification on morphology and metabolism of bovine blastocysts produced in vitro. Biology Reproduction, v. 65, n. 4, p. 1127-1134, 2001.

KAIDI, S.; DONNAY, I.; VAN LANGENDOCKT, A.; DESSY, F.; MASSIP, A. Comparision of two co-culture systems to assess the survival of in vitro produced bovine blastocysts after vitrification. Animal Reproduction Science, v. 52, n. 1, p. 39-50, 1998.

KAIDI, S.; VAN LANGENDOCKT, A.; MASSIP, A.; DESSY, F.; DONNAY, I. Cellular alteration after dilution of cryoprotective solutions used for the vitrification of in vitroproduced bovine embryos. Theriogenology, v. 52, n. 3, p. 515-525, 1999.

KANKA, J.; BRYOVA, A.; DURANTHON, V.; OUDIN, J. F.; PEYNOT, N.; RENARD, J. $P$. Identification of differentially expressed mRNA in bovine preimplantation embryos. Zygote, v. 11, n. 1, p. 43-52, 2003.

KARLSSON, J. O. M. A theoretical model of intracellular devitrification. Cryobiology, v. 42, n. , p. 154-169, 2001. 
KASAI, M.; ITO, K.; EDASHIGE, K. Morphological appearance of the cryopreserved mouse blastocyst as a tool to identify the type of cryoinjury. Human Reproduction, $v$. 17, n. 7, p.1863-1874, 2002.

KHOSLA, S.; DEAN, W.; REIK, W; FIEL, R. Culture of preimplantation embryos and is long-term effects on gene expression and phenotype. Human Reproduction Update, $\mathrm{v}$. 7, n. 4, p. 419-427, 2001.

KHURANA, N. K.; NIEMANN, H. Effects of cryopreservation on glucose metabolism and survival of bovine morulae and blastocysts derived in vitro or in vivo. Theriogenology, v. 54, n. 2, p. 313-326, 2000.

KRISHER, R. L.; BAVISTER, B. D. Responses of oocytes and embryos to the culture environment. Theriogenology, v. 49, n. , p. 103-114, 1998.

KULESHOVA, L. L.; LOPATA, A. Vitrification can be more favorable than slow cooling. Fertility and Sterility, v. 78, n. 3, p. 449-454, 2002.

KULESHOVA, L. L.; SHAW, J. M.; TROUNSON, A. O. Studies on replacing most of the penetrating cryoprotectant by polymers for embryo cryopreservation. Cryobiology, v. 43 , n. 1, p. 21-31, 2001.

LECHNIAK, D. Quantitative aspects of gene expression analysis in mammalian oocytes and embryos. Reproductive Biology, v. 2, n. 3, p. 299-241, 2002.

LEIBO, S. P.; LOSKUTOFF, N. M. Cryobiology of in vitro-derived bovine embryos. Theriogenology, v. 39, n. 1, p. 81-94, 1993.

LEONI, G.; BOGLIOLO, L.; BERLINGUER, F.; ROSATI, I.; PINTUS, P. P.; LEDDA, S.; NAITANA, S. Defined media for vitrification, warming, and rehydration: effects on postthaw protein synthesis and viability of in vitro derived ovine embryos. Cryobiology, v. 45, n. 3, p. 204-212, 2002.

LIEBERMANN, J.; NAWROTH, F.; ISACHENKO, V.; ISCHENKO, E.; RAHIMI, G.; TUCKER, M. J. Potential importance of vitrification in reproductive medicine. Biology of Reproduction, v. 67, n. 6, p. 1671-1680, 2002. 
LIM, K. T.; JANG, G.; KO, K. H.; LEE, W. W.; PARK, H. J.; KIM, J. J.; LEE, S. H.; HWANG, W. S.; LEE, B. C.; KANG, S. K. Improved in vitro bovine embryo development and increased efficiency in producing viable calves using defined media.

Theriogenology, v. 67, n. , p. 293-302, 2007.

LONERGAN, P.; FAIR, T.; CORCORAN, D.; EVANS, A. C. O. Effect of culture environment on gene expression and developmental characteristics in IVF-derived embryos. Theriogenology, v. 65, n. , p. 137-152, 2006.

LONERGAN, P.; RIZOS, D.; GUTIÉRREZ-ADÁN, A.; MOREIRA, P. M.; PINTADO, B.; DE LA FUETE, J. Temporal divergence in the pattern of messenger RNA expression in bovine embryos cultured from the zygote to blastocyst stage in vitro or in vivo. Biology of Reproduction, v. 69, n. 4, p. 1424-1431, 2003.

LONERGAN, P.; RIZOS, D.; KANKA, J.; NEMCOVA, L.; MBAYE, A., M.; KINGSTON, M.; WADE, M.; DUTTY, P.; BOLAND, M. P. Temporal sensitivity of bovine embryos to culture environment after fertilization and the implications for blastocyst quality

Reproduction, v. 126, n. 3, p. 337-346, 2003.

MAHMOUDZADEH, A. R.; VAN SOOM, A.; BOLS, P.; YSEBAERT, M. T.; KRUIF, A. Optimization of a simple vitrification procedure for bovine embryos produced in vitro: effect of developmental stage, two-step addition of cryoprotectant and sucrose dilution on embryonic survival. Journal of Reproduction and Fertility, v. 103, n. 1, p. 33-39, 1995.

MAHMOUDZADEH, A. R.; VAN SOOM, A.; YSEBAERT, M. T.; KRUIF, A. Comparison of two-step vitrification versus controlled freezing on survival of in vitro produced cattle embryos. Theriogenology, v. 42, n. 8, p. 1389-1397, 1994.

MARQUANT-LEGUIENNE, HUMBLOT, P. Practical measures to improve in vitro blastocyst production in the bovine. Theriogenology, v. 49, n. , p. 3-11, 1998.

MARQUEZ-ALVARADO, Y. C.; GALINA, C. S.; CASTILLA, B.; LÉON, H.; MORENOMENDONZA, N. Evidence of damage in cryopreserved and fresh bovine embryos using the Tunnel technique. Reproduction in Domestic Animals, v. 39, n. 3, p. 141-145, 2004. 
MARTINEZ, A. G.; VALCARCEL, A.; DE LÃS HERAS, M. A.; DE MATOS, D. G.; FURNUS, C.; BROGLIATTI, G. Vitrification of in vitro produced bovine embryos: in vitro and in vivo evaluations. Animal Reproduction Science, v. 73, n. , p. 11-21, 2002.

MASSIP, A.; MERMILLOD, P.; WILS, C.; DESSY, F. Effects of dilution procedure and culture conditions after thawing on survival of frozen bovine blastocysts procedure in vitro. Journal of Reproduction and Fertility, v. 97, n. 1, p. 65-69, 1993.

MASSIP, A.; VAN DER ZWALMEN, P.; SCHEFFEN, B.; ECTORS, F. Some significant steps in the cryopreservation of mammalian embryos with a note on a vitrification procedure. Animal Reproduction Science, v. 19, n. 1-2, p. 117-129, 1989.

MOHAN, M.; RYDER, S.; CLAYPOOL, P. L.; GEISERT, R. D.; MALAYER, J. R. Analysis of gene expression in the bovine blastocyst produced in vitro using suppression-subtractive hybridization. Biology of Reproduction, v. 67, n. 2, p. 447453, 2002.

MOORE, K.; BONILLA, A. Q. Cryopreservation of mammalian embryos: the state of the art. ARBS Annual Review of Biomedical Sciences. http://arbs.bibliotece.unesp.br2006,8:19-32.

MUCCI, N.; ALLER, J.; KAISER, G. G.; HOZBOR, F.; CABODEVILA, J.; ALBERIO, R. $\mathrm{H}$. Effect of estrous cow serum during bovine embryo culture on blastocyst development and cryotolerance alter show freezing or vitrification. Theriogenology, v. 65, n. 8, p. 1551-1562, 2005.

NATALE, D. R.; DE SOUSA, P. A.; WESTHUSIN, M. E.; WATSON, A. J. Sensitivity of bovine blastocyst gene expression patterns to culture environments assessed by differential display RT-PCR. Reproduction, v. 122, n. 5, p. 687-693, 2001.

NEDAMBALE, T. L.; DINNYÉS, A.; GROEN, W.; DOBRINSKY, J. R.; TIAN, X. C.; YANG, $X$. Comparison on in vitro fertilized bovine embryos cultured in KSOM or SOF and cryopreserved by slow freezing or vitrification. Theriogenology, v. 62, n. 3-4, p. 437-449, 2004.

NICACIO, A. C. Criopreservação e desenvolvimento in vitro de embriões bovinos. 200366 f. Dissertação (Mestrado em Medicina Veterinária) - Faculdade de Medicina Veterinária e Zootecnia, Universidade de São Paulo, São Paulo, 2003. 
OLIVEIRA, A. T. D.; LOPES, R. F. F.; RODRIGUES, J. L. Gene expression and development competence of bovine embryos produced in vitro under varying embryo density conditions. Theriogenology, v. 64, n. 7, p. 1559-1572, 2005.

PEREIRA, D. C.; DODE, M. A. N.; RUMPF, R. Evaluation of different culture systems on the in vitro production of bovine embryos. Theriogenology, v. 63, n. 4, p. 1131-1141, 2005.

PONSUKSILI, S.; TESFAYE, D.; EL-HALAWANY, N.; SCHELLANDER, K.; WIMMERS, K. Stage-specific expressed sequence tags obtained during preimplantation bovine development by differential display RT-PCR and suppression subtractive hybridization. Prenatal Diagnosis, v. 22, n. 12, p. 1135-1142, 2002.

PUGH, P. A.; TERVIT, H. R.; NIEMANN, H. Effects of vitrification medium composition on the survival of bovine in vitro produced embryos, following in straw-dilution, in vitro and in vivo following transfer. Animal Reproduction Science, v. 58, n. 1, p. 9-22, 2000.

RALL, W. F. Factors affecting the survival of mouse embryos cryopreserved by vitrification. Cryobiology, v. 24, n. 5, p. 387-402, 1987.

RALL, W. F.; FAHY, G. M. Vitrification: a news approach to embryo cryopreservation. Theriogenology, v. 23, n. 23, p. 220, 1985.

RIEF, S.; SINOWATZ, F.; STOJKOVIC, M.; EINSPANIER, R.; WOLF, E.; PRELL, K. Effects of novel co-culture system on development, metabolism and gene expression of bovine embryos produced in vitro. Reproduction, v. 124, n. 4, p. 543-556, 2002.

RIPAMONTE, P. Genômica funcional da ativação do genoma e do bloqueio embrionário em bovinos. 2005 101f. Tese (Doutorado em Zootecnia) - Faculdade de Zootecnia e Engenharia de Alimentos, Universidade de São Paulo, Pirassununga, 2005.

RIZOS, D.; GUTIÉRREZ-ADÁN, A.; PÉREZ-GARNELO, S.; DE LA FUENTE, J.; BOLAND, M. P.; LONERGAN, P. Bovine embryo culture in the presence or absence of serum: implications for blastocyst development, cryotolerance, and messenger RNA expression. Biology of Reproduction, v. 68, n. 1, p. 236-243, 2003. 
RIZOS, D.; LONERGAN, P.; BOLAND, M. P.; ARROYO-GRACÍA, R.; PINTADO, B.; DE LA FUENTE, J. Analysis of differential messenger RNA expression between bovine blastocysts produced in different culture systems: implications for blastocyst quality. Biology of Reproduction, v. 66, n. 3, p. 589-595, 2002.

RIZOS, D.; WARD, F.; BOLAND, M. P.; LONERGAN, P. Effect of culture system on the yield and quality of bovine blastocysts as assessed by survival after vitrification. Theriogenology, v. 56, n. 1, p. 1-16, 2001.

RIZOS, D.; WARD, F.; DUFFY, P.; BOLAND, M. P.; LONERGAN, P. Consequences of bovine oocyte maturation, fertilization or early embryo development in vitro versus in vivo: implications for blastocyst yield and blastocyst quality. Molecular Reproduction and Development, v. 61, n. 2, p. 234-248, 2002.

ROBERT, C.; MCGRAW, S.; MASSICOTTE, L.; PRAVETONI, M.; GANDOLFI, F.; SIRARD, M. A. Quantification of housekeeping transcript levels during the development of bovine preimplantation embryos. Biology of Reproduction, v. 67, n. , p. 1465-1472, 2002.

RUSSELL, D. F.; BAQIR, S.; BORDIGNON, J.; BETTS, D. H. The impact of oocyte maturation media on early bovine embryonic development. Molecular Reproduction and Development, v. 73, n. , p. 1255-1270, 2006.

SEIDEL JR., G. E. Modifying oocytes and embryos to improve their cryopreservation. Theriogenology, v. 65, n. , p. 228-235, 2006.

SILVA, F. M.; METELO, R. Relation between physical properties of zona pellucida and viability of bovine embryo after slow-freezing and vitrification. Reproduction in Domestic Animals, v. 40, n. 3, p. 205-209, 2005.

SIRARD, M. A.; DUFORT, I.; VALLÉE, M.; MASSICOTTE, L.; GRAVEL, C.; REGHENAS, H.; WATSON, A. J ; KING, W. A.; ROBERT, C. Potential and limitations of bovine-specific arrays for the analysis using a bovine embryonic array. Reproduction, Fertility and Development, v. 19, n. 1, p. 47-57, 2005.

SOMMERFELD, V.; NIEMANN, H. Cryopreservation of bovine in vitro produced embryos using ethylene glycol in controlled freezing or vitrification. Cryobiology, v. 38, n. 2, p. 95-105, 1999. 
STOJKOVIC, M.; KREBS, O.; KOLLE, S.; PRELLE, K.; ASSMANN, V.; ZAKHARTCHENKO, V.; SINOWATZ, F.; WOLF, E. Developmental regulation of hyaluronan-binding protein (RHAMM/IHABP) expression in early bovine embryos.

Biology of Reproduction, v. 68, n. 1, p. 60-66, 2003.

TACHIKAWA, S.; OTOI, T.; KONDO, S.; MACHIDA, T.; KASAI, M. Successful vitrification of bovine blastocysts, derived by in vitro maturation and fertilization. Molecular Reproduction and development, v. 34, n. 3, p. 266-271, 1993.

TAKAHASHI, M.; KEICHO, K.; TAKAHASHI, H.; OGAWA, H.; SCHULTZ, R. M.; OKANO, A. Effect of oxidative stress on development and DNA damage in in vitro cultured bovine embryos by comet assay. Theriogenology, v. 54, n. 1, p. 137-145, 2000.

TAKAMATSU, H.; RUBINSKY, B. Viability of deformed cells. Cryobiology, v. 39, n. , p. 243-251, 1999.

TESFAYE, D.; PONSUKSILI, S.; WIMMERS, K.; GILLES, M.; SCHELLANDER, K. Identification and quantification of differentially expressed transcripts in vitro-produced bovine preimplantation stage embryos. Molecular Reproduction and Development, v. 66 , n. 2, p. 105-114, 2003.

THOMPSON, J. G. Comparison between in vitro-derived and in vitro-produced preelongation embryos from domestic ruminants. Reproduction, Fertility and Development, v. 9, n. , p. 341-354, 1997.

VAJTA, G. Vitrification of bovine oocytes and embryos. Embryo Transfer Newsletter, v. 15, n. ,p. 15-26, 1997.

VAJTA, G.; BOOTH, P. J.; HOLM, P.; GREVE, T.; CALLESEN, H. Successful vitrification of early stage bovine in vitro produced embryos with the open pulled straw (OPS) method. Cryo-letters, v. 18, n. ,p. 191-195, 1997.

VAJTA, G.; HOLM, P.; GREVE, T.; CALLESEN, H. Factors affecting survival rates of in vitro produced bovine embryos after vitrification and direct in-straw rehydration. Animal Reproduction Science, v. 45, n. , p. 191-200, 1996. 
VAJTA, G.; HYTTEL, P.; CALLESEN, H. Morphological changes of in vitro produced bovine blastocysts after vitrification, in straw direct rehydration, and culture. Molecular Reproduction and Development, v. 48, n. 1, p. 9-17, 1997.

VAJTA, G.; RINDOM, N.; PEURA, T. T.; HOLM, P.; GREVE, T.; CALLESEN, H. The effect of media, serum and temperature on in vitro survival of bovine blastocysts after open pulled straw (OPS) vitrification. Theriogenology, v. 52, n. 5, p. 939-948, 1999.

VAN WAGTENDONK-DE LEEUW, A. M.; DEN DAAS, J. H. G.; KRUIP, T. H. G. A. M.; RALL, W. F. Comparision of the efficacy of conventional slow freezing and rapid cryopreservation methods for bovine embryos. Cryobiology, v. 32, n. , p. 157-167, 1995.

WALKER, D. J.; CAMPOS-CHILLON, L. F.; SEIDEL, G. E. Vitrification of in vitroproduced bovine embryos by addition of ethylene glycol in one-step. Reproduction in Domestic Animals, v. 41, n. , p. 467-471, 2006.

WRENZYCKI, C.; HERRMANN, D.; NIEMANN, H. Messenger RNA in oocytes and embryos in relation to embryo viability. Theriogenology, v. 68, n. , p. 77-83, 2007. Supplement.

WRENZYCKI, C.; HERRMANN, D.; NIEMANN, H. Timing of blastocyst expansion affects spatial messenger RNA expression patterns of genes in bovine blastocysts produced in vitro. Biology of Reproduction, v. 68, n. 6, p. 2073-2080, 2003.

ZIMMERMANN, J. W.; SCHULTZ, R. M. Analysis of gene expression in the preimplantation mouse embryo: use of mRNA differential display. Proceedings of the National Academy of Sciences of the United States of America, v. 91, n. 12, p. 5456-5460, 1994. 


\section{Anexos}




\section{ANEXOS}

Anexo A - Soluções Estoque para Produção de Embriões

\section{A.1 - Solução de Gentamicina (10 $\mathrm{mg} / \mathrm{ml})$}

\begin{tabular}{|c|c|c|}
\hline Reagente & Quantidade & Código \\
\hline Gentamicina & $0,1000 \mathrm{~g}$ & Sigma® (G-1264) \\
\hline Solução Fisiológica & $10 \mathrm{ml}$ & \\
\hline
\end{tabular}

Armazenamento: freezer $\left(-20^{\circ} \mathrm{C}\right)$

Validade: 6 meses

\section{A.2 - Solução de Piruvato $(0,2 \mathrm{mM})$}

\begin{tabular}{|c|c|c|}
\hline Reagente & Quantidade & Código \\
\hline Piruvato & $0,1320 \mathrm{~g}$ & Sigma $®(\mathrm{P}-4562)$ \\
\hline Solução Fisiológica & $12 \mathrm{ml}$ & \\
\hline
\end{tabular}

Armazenamento: freezer $\left(-20^{\circ} \mathrm{C}\right)$

Validade: 6 meses

\section{A.3 - Solução de Estradiol $(1 \mathrm{mg} / \mathrm{ml})$}

\begin{tabular}{|c|c|c|}
\hline Reagente & Quantidade & Código \\
\hline Estradiol & $0,02041 \mathrm{~g}$ & Sigma ${ }^{\circledR}(\mathrm{E}-4389)$ \\
\hline Água MiliQ & $1 \mathrm{ml}$ & \\
\hline
\end{tabular}

Armazenamento: freezer $\left(-20^{\circ} \mathrm{C}\right)$

Validade: 6 meses 


\section{A.4 - Solução de FSH}

\section{A.4.1 - Solução "Mãe”}

\begin{tabular}{|c|c|c|}
\hline Reagente & Quantidade & Código \\
\hline Folltropin® $(400 \mathrm{mg})$ & & \\
\hline Solução Fisiológica & $2 \mathrm{ml}$ & \\
\hline
\end{tabular}

Armazenamento: freezer $\left(-20^{\circ} \mathrm{C}\right)$

Validade: 6 meses

\section{A.4.2 - Solução FSH $(0,5 \mathrm{mg} / \mathrm{ml})$}

\begin{tabular}{|c|c|c|}
\hline Reagente & Quantidade & Código \\
\hline Solução "Mãe" & $50 \mu \mathrm{l}$ & \\
\hline $\begin{array}{c}\text { TCM199 Sodium } \\
\text { Bicarbonate }\end{array}$ & $20 \mathrm{ml}$ & Gibco® (11150-059) \\
\hline
\end{tabular}

Armazenamento: freezer $\left(-20^{\circ} \mathrm{C}\right)$

Validade: 6 meses

\section{A.5 - Solução de LH (700Ul/ml)}

\begin{tabular}{|c|c|c|}
\hline Reagente & Quantidade & Código \\
\hline Chorulon $®(5000 \mathrm{UI})$ & & Intervet $®(\mathrm{hCG})$ \\
\hline $\begin{array}{c}\text { TCM199 Sodium } \\
\text { Bicarbonate }\end{array}$ & $7,14 \mathrm{ml}$ & Gibco $\AA(11150-059)$ \\
\hline
\end{tabular}

Armazenamento: freezer $\left(-20^{\circ} \mathrm{C}\right)$

Validade: 6 meses 
A.6 - Solução 10X

A.6.1 - Solução KCI (1M)

\begin{tabular}{|c|c|c|}
\hline Reagente & Quantidade & Código \\
\hline $\mathrm{KCl}$ & $0,3725 \mathrm{~g}$ & Sigma $®(\mathrm{P}-4504)$ \\
\hline $\mathrm{H}_{2} \mathrm{O}$ MiliQ & $5 \mathrm{ml}$ & \\
\hline
\end{tabular}

A.6.2 - Solução $\mathrm{NaH}_{2} \mathrm{PO}_{4} \cdot \mathrm{H}_{2} \mathrm{O}(0,1 \mathrm{M})$

\begin{tabular}{|c|c|c|}
\hline Reagente & Quantidade & Código \\
\hline $\mathrm{NaH}_{2} \mathrm{PO}_{4} \cdot \mathrm{H}_{2} \mathrm{O}$ & $0,0690 \mathrm{~g}$ & Sigma ${ }^{\circledR}(\mathrm{S}-5011)$ \\
\hline $\mathrm{H}_{2} \mathrm{O} \mathrm{MiliQ}$ & $5 \mathrm{ml}$ & \\
\hline
\end{tabular}

\section{A.6.3 - Solução 10X (final)}

\begin{tabular}{|c|c|c|}
\hline Reagente & Quantidade & Código \\
\hline $\mathrm{KCl}(1 \mathrm{M})$ & $772,5 \mu \mathrm{l}$ & \\
\hline $\mathrm{NaH}_{2} \mathrm{PO}_{4} \cdot \mathrm{H}_{2} \mathrm{O}(0,1 \mathrm{M})$ & $730,0 \mu \mathrm{l}$ & Sigma ${ }^{\circledR}(\mathrm{S}-9625)$ \\
\hline $\mathrm{NaCl}$ & $1,1687 \mathrm{~g}$ & Sigma ${ }^{\circledR}(\mathrm{H}-0891)$ \\
\hline $\mathrm{HEPES}$ & $0,5950 \mathrm{~g}$ & \\
\hline $\mathrm{H}_{2} \mathrm{O} \mathrm{MiliQ}$ & $25 \mathrm{ml}$ (q.s.p.) & \\
\hline
\end{tabular}

Armazenamento: freezer $\left(-20^{\circ} \mathrm{C}\right)$

Validade: 6 meses 
A.7 - Solução de $\mathrm{CaCl}_{2}(1 \mathrm{M})$

\begin{tabular}{|c|c|c|}
\hline Reagente & Quantidade & Código \\
\hline $\mathrm{CaCl}_{2}$ & $0,7350 \mathrm{~g}$ & Sigma $\mathbb{}$ \\
\hline $\mathrm{H}_{2} \mathrm{O} \mathrm{MiliQ}$ & $5 \mathrm{ml}$ & \\
\hline
\end{tabular}

Armazenamento: geladeira $\left(4^{\circ} \mathrm{C}\right)$

Validade: 4 meses

\section{A.8 - Solução de Heparina $(10 \mathrm{mg} / \mathrm{ml})$}

\begin{tabular}{|c|c|c|}
\hline Reagente & Quantidade & Código \\
\hline Heparina & $0,0200 \mathrm{~g}$ & Sigma $\AA(\mathrm{H}-3149)$ \\
\hline Meio FIV & $2 \mathrm{ml}$ & \\
\hline
\end{tabular}

Armazenamento: freezer $\left(-20^{\circ} \mathrm{C}\right)$

Validade: 6 meses

\section{A.9 - Solução de $\mathrm{MgCl}_{2}(0,1 \mathrm{M})$}

\begin{tabular}{|c|c|c|}
\hline Reagente & Quantidade & Código \\
\hline $\mathrm{MgCl}_{2}$ & $0,1015 \mathrm{~g}$ & Sigma $\AA$ \\
\hline $\mathrm{H}_{2} \mathrm{O} \mathrm{MiliQ}$ & $5 \mathrm{ml}$ & \\
\hline
\end{tabular}

Armazenamento: geladeira $\left(4^{\circ} \mathrm{C}\right)$

Validade: 4 meses 
A.10 - Solução PHE

A.10.1 - Solução de Penicilamina $(2 \mu \mathrm{M})$

\begin{tabular}{|c|c|c|}
\hline Reagente & Quantidade & Código \\
\hline DL - Penicillamine & $0,0030 \mathrm{~g}$ & Sigma ${ }^{\circledR}(\mathrm{P}-5125)$ \\
\hline Solução Fisiológica & $10 \mathrm{ml}$ & \\
\hline
\end{tabular}

\section{A.10.2 - Solução de Hipotaurina $(1 \mu M)$}

\begin{tabular}{|c|c|c|}
\hline Reagente & Quantidade & Código \\
\hline Hypotaurine & $0,00109 \mathrm{~g}$ & Sigma® $(\mathrm{H}-1384)$ \\
\hline Solução Fisiológica & $10 \mathrm{ml}$ & \\
\hline
\end{tabular}

\section{A.10.3 - Solução de Epinefrina $(0,25 \mu \mathrm{M})$}

\begin{tabular}{|c|c|c|}
\hline Reagente & Quantidade & Código \\
\hline Epinephrine & $0,00183 \mathrm{~g}$ & Sigma $\AA(E-4250)$ \\
\hline Solução $\mathrm{pH} 4.0$ & $40 \mathrm{ml}$ & \\
\hline
\end{tabular}


A.10.4 - Solução pH 4.0

\begin{tabular}{|c|c|c|}
\hline Reagente & Quantidade & Código \\
\hline Na-lactato & $125,9 \mu \mathrm{l}$ & \\
\hline Na-metabisulfite & $0,0500 \mathrm{~g}$ & \\
\hline $\mathrm{H}_{2} \mathrm{O}$ MiliQ & $50 \mathrm{ml}$ & \\
\hline
\end{tabular}

${ }^{\star}$ Corrigir o pH com solução $1 \mathrm{~N}$ de $\mathrm{HCl}$

\section{A.10.5 - Solução $1 \mathrm{~N}$ de HCI}

\begin{tabular}{|c|c|c|}
\hline Reagente & Quantidade & Código \\
\hline $\mathrm{HCl}$ & $8,28 \mathrm{ml}$ & \\
\hline Água MilliQ & $100 \mathrm{ml}$ & \\
\hline
\end{tabular}

A.10.6 - Solução PHE (final)

\begin{tabular}{|c|c|c|}
\hline Reagente & Quantidade & Concentração \\
\hline Solução de Penicilamina & $2,5 \mathrm{ml}$ & $0,270 \mu \mathrm{g} / 100 \mathrm{ml}$ \\
\hline Solução de Hipotaurina & $2,5 \mathrm{ml}$ & $0,100 \mu \mathrm{g} / 100 \mathrm{ml}$ \\
\hline Solução de Epinefrina & $2,0 \mathrm{ml}$ & $0,033 \mu \mathrm{g} / 100 \mathrm{ml}$ \\
\hline Solução Fisiológica & $4,0 \mathrm{ml}$ & \\
\hline
\end{tabular}

Armazenamento: freezer $\left(-20^{\circ} \mathrm{C}\right)$

Validade: 6 meses 
A.11 - Solução TL Sêmen

\begin{tabular}{|c|c|c|}
\hline Reagente & Quantidade & Código \\
\hline $\mathrm{NaCl}$ & $0,0873 \mathrm{~g}$ & Sigma ${ }^{\circledR}(\mathrm{S}-9625)$ \\
\hline $\mathrm{KCl}$ & $0,00345 \mathrm{~g}$ & Sigma ${ }^{\circledR}(\mathrm{P}-4504)$ \\
\hline $\mathrm{MgCl}_{2}{ }^{*}$ & $0,0012 \mathrm{~g}$ & Sigma ${ }^{\circledR}(\mathrm{S}-5011)$ \\
\hline $\mathrm{NaH}_{2} \mathrm{PO}_{4}$ & $0,00052 \mathrm{~g}$ & Sigma ${ }^{\circledR}(\mathrm{S}-5761)$ \\
\hline $\mathrm{NaHCO}_{3}$ & $0,0315 \mathrm{~g}$ & \\
\hline $\mathrm{CaCl}_{2} \mathrm{H}_{2} \mathrm{O}^{*}$ & $0,0045 \mathrm{~g}$ & Sigma $(\mathrm{P}-4633)$ \\
\hline Phenol Red & $0,00015 \mathrm{~g}$ & Sigma ${ }^{\circledR}(\mathrm{L}-7900)$ \\
\hline DL-Lactic Acid & $46,5 \mu \mathrm{l}$ & Sigma ${ }^{\circledR}(\mathrm{H}-0891)$ \\
\hline Hepes & $0,0357 \mathrm{~g}$ & \\
\hline Água MiliQ qsp & $15 \mathrm{ml}$ & \\
\hline
\end{tabular}

* Pesar separadamente $\mathrm{pH}=7,4 ; \mathrm{OSM}=295-300$

Armazenamento: geladeira $\left(4^{\circ} \mathrm{C}\right)$

Validade: 2 semanas

\section{A.12 - Solução TL Stock}

\begin{tabular}{|c|c|c|}
\hline Reagente & Quantidade & Código \\
\hline $\mathrm{NaCl}$ & $0,1665 \mathrm{~g}$ & 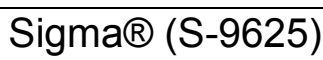 \\
\hline $\mathrm{KCl}$ & $0,0060 \mathrm{~g}$ & Sigma ${ }^{\circledR}(P-4504)$ \\
\hline $\mathrm{MgCl}_{2}{ }^{*}$ & $0,0025 g$ & \\
\hline $\mathrm{NaH}_{2} \mathrm{PO}_{4}$ & $0,00102 g$ & Sigma ${ }^{\circledR}(\mathrm{S}-5011)$ \\
\hline $\mathrm{NaHCO}_{3}$ & $0,0525 \mathrm{~g}$ & Sigma ${ }^{\circledR}(\mathrm{S}-5761)$ \\
\hline $\mathrm{CaCl}_{2} \mathrm{H}_{2} \mathrm{O}^{*}$ & $0,0075 \mathrm{~g}$ & \\
\hline Phenol Red & $0,00025 \mathrm{~g}$ & 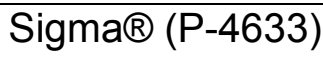 \\
\hline DL - Lactic Acid & $35,75 \mu l$ & 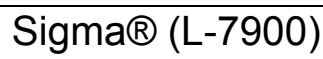 \\
\hline Água MiliQ qsp & $25 \mathrm{ml}$ & \\
\hline
\end{tabular}

* Pesar separadamente

$\mathrm{pH}=7,4 ;$ OSM = 295-300

Armazenamento: geladeira $\left(4^{\circ} \mathrm{C}\right)$

Validade: 2 semanas 


\section{A.13 - SOF (Estoque)}

\begin{tabular}{|c|c|c|}
\hline Reagente & Quantidade & Código \\
\hline $\mathrm{NaCl}$ & 0,6294 & Sigma ${ }^{\circledR}(\mathrm{S}-9625)$ \\
\hline $\mathrm{KCl}$ & 0,0534 & Sigma $®(P-4504)$ \\
\hline $\mathrm{KH}_{2} \mathrm{PO}_{4}$ & 0,0162 & Sigma ${ }^{\circledR}(P-5655)$ \\
\hline $\mathrm{NaHCO}_{3}$ & 0,2106 & Sigma® (S-5761) \\
\hline Na lactato & 0,0370 & \\
\hline DL - Lactic Acid & & 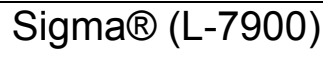 \\
\hline Phenol red & 0,00013 & Sigma ${ }^{\circledR}(P-4633)$ \\
\hline L-glutamina & 0,0146 & Sigma® (G-1517) \\
\hline $\mathrm{MgCl}_{2} 7 \mathrm{H}_{2} \mathrm{O}^{*}$ & 0,0098 & \\
\hline $\mathrm{CaCl}_{2}{ }^{*}$ & 0,0252 & \\
\hline
\end{tabular}

* Pesar separadamente

Armazenamento: geladeira $\left(4^{\circ} \mathrm{C}\right)$

Validade: 2 meses 


\section{Anexo B - Meios de uso para produção de embriões}

Preparados no dia que serão utilizados. Todos os meios de uso são filtrados em filtro Millipore $0,22 \mu \mathrm{m}$.

\section{B.1 - Meio de Lavagem para MIV (Pré-MIV)}

\begin{tabular}{|c|c|c|}
\hline Reagente & Quantidade & Concentração \\
\hline $\begin{array}{c}\text { TCM 199 com HEPES } \\
(\text { Gibco®) }\end{array}$ & $4,5 \mathrm{ml}$ & \\
\hline Soro Fetal Bovino (SFB) & $0,5 \mathrm{ml}$ & $(10 \%)$ \\
\hline Piruvato & $10 \mu \mathrm{l}$ & $(0,05 \mathrm{mg} / \mathrm{ml})$ \\
\hline Gentamicina & $25 \mu \mathrm{l}$ & \\
\hline
\end{tabular}

\section{B.2 - Meio de Maturação (MIV)}

\begin{tabular}{|c|c|c|}
\hline Reagente & Quantidade & Concentração \\
\hline $\begin{array}{c}\text { TCM199 Sodium Bicarbonate } \\
(\text { Gibco® - 11150-059) }\end{array}$ & $4,5 \mathrm{ml}$ & \\
\hline SFB & $0,5 \mathrm{ml}$ & $(10 \%)$ \\
\hline Piruvato & $10 \mu \mathrm{l}$ & $(0,05 \mathrm{mg} / \mathrm{ml})$ \\
\hline Gentamicina & $25 \mu \mathrm{l}$ & $(0,5 \mu \mathrm{g} / \mathrm{ml})$ \\
\hline FSH & $5 \mu \mathrm{l}$ & $(7 \mathrm{Ul} / \mathrm{ml})$ \\
\hline LH & $50 \mu \mathrm{l}$ & $(\sim 1 \mu \mathrm{g} / \mathrm{ml})$ \\
\hline Estradiol & $5 \mu \mathrm{l}$ & \\
\hline
\end{tabular}

${ }^{*}$ Acrescentar após filtrar 
B.3 - Meio de Lavagem para FIV (Pré-FIV)

\begin{tabular}{|c|c|c|}
\hline Reagente & Quantidade & Concentração \\
\hline $\begin{array}{c}\text { TCM-199 com HEPES } \\
(\text { Gibco®) }\end{array}$ & $10 \mathrm{ml}$ & \\
\hline $\begin{array}{c}\text { BSA - V (Sigma } \AA \text { A- } \\
9647)\end{array}$ & $0,030 \mathrm{~g}$ & \\
\hline Piruvato & $20 \mu \mathrm{l}$ & \\
\hline Gentamicina & $50 \mu \mathrm{l}$ & $(0,05 \mathrm{mg} / \mathrm{ml})$ \\
\hline
\end{tabular}

\section{B.4 - Meio de Fecundação (FIV)}

\begin{tabular}{|c|c|c|}
\hline Reagente & Quantidade & Concentração \\
\hline TL - Stock & $5 \mathrm{ml}$ & \\
\hline $\begin{array}{c}\text { BSA - Livre de Ácidos } \\
\text { Graxos (Sigma } ® \text { A-6003) }\end{array}$ & $0,030 \mathrm{~g}$ & \\
\hline Piruvato & $10 \mu \mathrm{l}$ & $(0,05 \mathrm{mg} / \mathrm{ml})$ \\
\hline Gentamicina & $25 \mu \mathrm{l}$ & \\
\hline
\end{tabular}

\section{B.5 - Meio FIV Gota (Gota)}

\begin{tabular}{|l|c|c|}
\hline \multicolumn{1}{|c|}{ Reagente } & Quantidade & Concentração \\
\hline Meio FIV & $3.640 \mu \mathrm{l}$ & \\
\hline Heparina & $40 \mu \mathrm{l}$ & $(100 \mathrm{mg} / \mathrm{ml})$ \\
\hline PHE & $160 \mu \mathrm{l}$ & \\
\hline
\end{tabular}




\section{B.6 - Percoll 90\%}

\begin{tabular}{|l|c|l|}
\hline \multicolumn{1}{|c|}{ Reagente } & Quantidade & Concentração \\
\hline Percoll (Sigma® P-1644) & $3,6 \mathrm{ml}$ & \\
\hline Solução $10 x$ & $0,4 \mathrm{ml}$ & \\
\hline $\mathrm{CaCl}_{2} 2 \mathrm{H}_{2} \mathrm{O} 1 \mathrm{M}$ & $8 \mu \mathrm{l}$ & \\
\hline $\mathrm{MgCl}_{2} 6 \mathrm{H}_{2} \mathrm{O} 0,1 \mathrm{M}$ & $15,6 \mu \mathrm{l}$ & \\
\hline $\mathrm{Na} \mathrm{Lactato}$ & $14,8 \mu \mathrm{l}$ & \\
\hline $\mathrm{NaHCO}_{3}$ (Sigma® S-5761) & & \\
\hline
\end{tabular}

\section{B.7 - Percoll 45\%}

\begin{tabular}{|l|c|c|}
\hline \multicolumn{1}{|c|}{ Reagente } & Quantidade & Concentração \\
\hline Percoll $90 \%$ & $1 \mathrm{ml}$ & \\
\hline TL Sêmen & $1 \mathrm{ml}$ & \\
\hline
\end{tabular}

\section{B.8 - Meio de cultivo (SOFaa)}

\begin{tabular}{|c|c|c|}
\hline Reagente & Quantidade & Concentração \\
\hline SOF estoque & $4,6 \mathrm{ml}$ & $(5 \%)$ \\
\hline SFB & $0,25 \mathrm{ml}$ & Sigma $(\mathrm{M}-5550)$ \\
\hline Aminoácidos essenciais & $100 \mu \mathrm{l}$ & Sigma ${ }^{(M-7145)}$ \\
\hline $\begin{array}{c}\text { Aminoácidos não } \\
\text { essenciais }\end{array}$ & $50 \mu \mathrm{l}$ & \\
\hline
\end{tabular}


B.9 - Meio de cultivo (TCM199)

\begin{tabular}{|c|c|c|}
\hline Reagente & Quantidade & Concentração \\
\hline $\begin{array}{c}\text { TCM199 Sodium } \\
\text { Bicarbonate (Gibco® - } \\
\text { 11150-059) }\end{array}$ & $4,5 \mathrm{ml}$ & \\
\hline SFB & $0,5 \mathrm{ml}$ & $(10 \%)$ \\
\hline Piruvato & $10 \mu \mathrm{l}$ & \\
\hline Gentamicina & $25 \mu l$ & $(0,05 \mathrm{mg} / \mathrm{ml})$ \\
\hline
\end{tabular}


Anexo C - MEIOS DE CONGELAÇÃo

C.1 - Meio de Lavagem dos embriões (LAV)

\begin{tabular}{|c|c|c|}
\hline Reagente & Quantidade & Concentração \\
\hline PBS & $3,0 \mathrm{ml}$ & \\
\hline BSA V (Sigma $® A-9647)$ & $0,02 g$ & \\
\hline
\end{tabular}

C.2 - Meio das extremidades das palhetas (SAC)

\begin{tabular}{|l|c|c|}
\hline \multicolumn{1}{|c|}{ Reagente } & Quantidade & Concentração \\
\hline PBS & $3,0 \mathrm{ml}$ & \\
\hline BSA V (Sigma $\AA$ A-9647) & $0,02 \mathrm{~g}$ & \\
\hline Sacarose (Sigma $\circledR$ & $0,5 \mathrm{~g}$ & \\
\hline
\end{tabular}

C.3 - Solução de 10\% de Etileno Glicol (EG10)

\begin{tabular}{|c|c|c|}
\hline Reagente & Quantidade & Concentração \\
\hline PBS & $4,5 \mathrm{ml}$ & \\
\hline BSA V (Sigma® A-9647) & $0,02 g$ & \\
\hline Etileno Glicol & $0,5 \mathrm{ml}$ & $(10 \%)$ \\
\hline
\end{tabular}


C.4 - Solução de 20\% de Etileno Glicol e 20\% de Glicerol (EG20/Gli20)

\begin{tabular}{|l|c|c|}
\hline \multicolumn{1}{|c|}{ Reagente } & Quantidade & Concentração \\
\hline PBS & $3,0 \mathrm{ml}$ & \\
\hline BSA V (Sigma® A-9647) & $0,02 \mathrm{~g}$ & $(20 \%)$ \\
\hline Etileno Glicol & $1,0 \mathrm{ml}$ & $(20 \%)$ \\
\hline Glicerol (Sigma® G-5516) & $1,0 \mathrm{ml}$ & \\
\hline
\end{tabular}

C.5 - Solução de 25\% de Etileno Glicol e 25\% de Glicerol (EG25/Gli25)

\begin{tabular}{|l|c|c|}
\hline \multicolumn{1}{|c|}{ Reagente } & Quantidade & Concentração \\
\hline PBS & $2,5 \mathrm{ml}$ & \\
\hline BSA V (Sigma® A-9647) & $0,02 \mathrm{~g}$ & $(25 \%)$ \\
\hline Etileno Glicol & $1,25 \mathrm{ml}$ & $(25 \%)$ \\
\hline Glicerol (Sigma® G-5516) & $1,25 \mathrm{ml}$ & \\
\hline
\end{tabular}

